\title{
Geochronological and geochemical characterization of magmatic-hydrothermal events within the Southern Variscan external domain (Cévennes area, France)
}

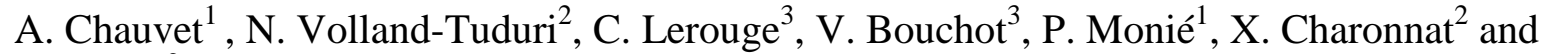 \\ M. Faure
}

(1) Géosciences Montpellier, UMR 5243, Univ. Montpellier II, cc 60, 34095 Montpellier Cedex 05, France

(2) Université d'Orléans, UMR 6113, ISTO, Campus Géosciences, 1A rue de la Férollerie, BP 6759, 45071 Orléans Cedex 2, France

(3) BRGM, 3 avenue Claude Guillemin, BP 6009, 45060 Orléans Cedex 2, France

\begin{abstract}
Geochronological, mineralogical, and geochemical analyses have been focussed on the MontLozère-Borne plutonic complex and surrounding rocks (Cévennes, French Massif Central) in which $\mathrm{B}-\mathrm{W}-\mathrm{Sn}$ and As-Au-Sb mineralization is encountered. Two main results are highlighted: (1) the existence of a 301-306 Ma magmato-hydrothermal event unrelated to the emplacement of the Pont-de-Montvert-Borne plutonic body at $316 \mathrm{Ma}$; (2) the magmatic and hydrothermal features are strongly associated, both in time and in space, thus demonstrating an intimate connection between mineralizing processes and magmatism in this part of the French Massif Central. We also show that mineralization and associated hydrothermal occurrences do not correspond to a simple and single geochemical signature and that a contamination model must be invoked in order to account for the complexity of isotopic results. This study demonstrates that the application of the $\mathrm{O}$ and $\mathrm{H}$ isotopic signatures as tracers of the source and nature of fluids in an orogenic context requires some specific care. Finally, a model of the tectonic-magmatic-hydrothermal evolution of the study area is suggested in which we discuss two alternative scenarios. The first one implies the existence of two different hydrothermal/mineralizing events (Bo-W-Sn and As-Au-Sb ones). The second one suggests the same source for all hydrothermal and mineralized structures.
\end{abstract}

Keywords ${ }^{40} \mathrm{Ar} /{ }^{39} \mathrm{Ar}$ dating - $(\mathrm{H}, \mathrm{O})$ isotope geochemistry - Granite - Hydrothermalism Aplite and pegmatite dykes - Cévennes - Variscan - French Massif central

Introduction

Recent investigations into the late Variscan evolution of the French Massif Central have pointed out that numerous mineral deposits ( $\mathrm{Au}, \mathrm{Sb}, \mathrm{W}, \mathrm{Sn}$, rare metal) formed at the end of the orogenic evolution (Bouchot et al. 1997; Marignac and Cuney 1999) represent the economic products of two distinct mineralizing systems, namely B-W-Sn and As-Au-Sb. Mineralization mainly occurs as structurally controlled quartz vein type. The emplacement of these two types of mineralization took place after the peak of regional metamorphism, during a short time span at ca. 310-300 Ma. This fertile period coincides with the end of syncollisional extension and the beginning of the post-collisional extension (Bouchot et al. 2005). The gold deposits, interpreted as orogenic lode gold deposit type (Groves et al. 1998), are related to crustal-scale hydrothermal plumbing system, whereas the W-Sn and/or rare metal deposit are usually related to metal-bearing leucogranite. 
In the Cévennes area, most of ore deposits belong to the As-Au-Sb system, and their emplacement results from the late Variscan extensional collapse stage (e.g. Charonnat et al. 1999; Faure et al. 1999). Furthermore, other hydrothermal and magmatic occurrences led to the definition of a km-scale magmato-hydrothermal system, centered on the Mont-LozèreBorne pluton (Charonnat 2000) and containing at least two generations of magma-related features: porphyritic monzogranite s.s. and aplite-pegmatite dyke and sill swarms. However, a genetic model has not been clearly established, and the nature and source of the mineralizing fluids (i.e., meteoric, metamorphic and/or magmatic) are still points of debate. Because hydrothermalism is classically assumed to develop in relation to granite occurrence (Marignac and Cuney 1999; Pichavant 1993; Williamson et al. 1996), it is herein intented (1) to better constrain the genetic relationships between magmatism and neighboring hydrothermal features, (2) to establish an accurate chronology by dating the hydrothermal and magmatic events, and (3) to determine the fluid origin for these occurrences.

Based on combined mineralogical and isotopic analyses, mainly obtained on quartz and tourmaline, a correlation between the different magmatic occurrences and the hydrothermal features is proposed and discussed in the light of ${ }^{40} \mathrm{Ar} /{ }^{39} \mathrm{Ar}$ geochronology. A tectono-thermal evolution of this orogenic segment in which late magmatic and hydrothermal structures are highly connected is discussed in conclusion.

Geological setting

The Variscan Belt

The Variscan Belt of Western Europe, extending from the Iberian Peninsula to Polish Sudetes, results from the collision between Gondwana and Laurussian continents, and several intercalated microcontinents (i.e. Armorica, Autran and Cogné 1980; Faure et al. 2005; Matte 1986, Paris and Robardet 1990). It is characterized by a discontinuous and polycyclic evolution developed during the Paleozoic (e.g. Faure et al. 1997). A Late Silurian-Early Devonian Eo-Variscan stage is responsible for the formation of high-pressure metamorphic rocks and their exhumation in relation to continental subduction. This early stage is well preserved in the upper allochthonous unit (or Upper Gneiss Unit, Ledru et al. 1989) and was followed by the main Variscan orogeny during Devonian-Carboniferous times. The Variscan tectogenesis is characterized by nappe stacking coeval with medium-pressure/mediumtemperature metamorphism. A significant crustal thickening $(50-60 \mathrm{~km})$ causes the melting of the lower and middle crust, between Carboniferous and Permian times. Consequently, a voluminous calc-alkaline to peraluminous granitic magmatism takes place during the Carboniferous, linked with syn- and post-collisional extensional tectonics related to the late orogenic collapse (Faure 1995).

A metalliferous event, marked by the emplacement of W-As-Au-Sb mineralization, developed around 310-300 Ma (Bouchot et al. 2005). Chronologically, it coincides with the main extensional stage and with the low-pressure/high-temperature granulitization event responsible for leucogranites emplacement (Bouchot et al. 2005; Marignac and Cuney 1999; Pichavant 1993, Williamson et al. 1996,). Several works have demonstrated the geometrical link between ore deposits and extensional features (Charonnat et al. 1999, Faure et al. 2001) or combination between local extension and horizontal shortening (Bouchot et al. 2005). In fact, because ore districts are frequently located close to granitic plutons (e.g. Limousin, Cévennes and Châtaigneraie areas), anatectic domes (e.g. Montagne Noire Velay, Laumonier et al. 1991) or related to crustal-scale faults (e.g. the Argentat domain, Roig et al. 1997), it has been suggested that magmatism and normal faulting certainly played a significant role, 
respectively, as thermal engine and fluid channeling conduct for the process of ore concentration. In the Cévennes area, the fact that As anomaly is concentrated around the main plutons is an additional argument for a significant role played by magmatism in the mineralizing process.

\section{The Cévennes area}

Located southeast of the French Massif Central, the Cévennes area belongs to the paraautochthonous unit (Ledru et al. 1989). It is characterized by a stack of thrust sheets composed of sericite-biotite micaschists, quartzites, and graphite-rich black micaschists (Brouder 1963; Faure et al. 2001 and enclosed references; Guerangé-Lozes and Pelet 1990) (Fig. 1). Several Namurian-Westphalian granitic plutons coeval with the late orogenic extensional tectonics intrude the metamorphic pile. Eastward, the terrigeneous sedimentary rocks of the Late Carboniferous Stephanian Alès coal basin unconformably overly the metamorphic formations (Fig. 1)

In this part of the Cévennes area, plutonic rocks crop out in the Mont-Lozère and Borne massifs (Fig. 1). The Mont-Lozère massif is composed by two main petrographic facies, the two micas leucogranite (Signaux pluton), developed in the northern part of the batholith and the porphyritic monzogranite (Pont-de-Montvert, Rabeyrals and Les Bondons) in the south (Mialhe 1980; Sabourdy and Berthelay 1977; Van Moort 1966). To the east of the left-lateral Villefort wrench fault, the Borne massif consists of the same porphyritic facies as the Pont-deMontvert monzogranite. In fact, these two entities belong to a single intrusion, called the Pont-de-Montvert-Borne granite, dated by $\mathrm{Rb}-\mathrm{Sr}$ whole-rock method at $315+5 \mathrm{Ma}$ (Mialhe 1980). The Bougès facies, even if it does not exhibit a porphyritic aspect, yields a crystallization age of $316+4 \mathrm{Ma}$ (U/Pb on monazite, Brichau et al. 2007). An ${ }^{40} \mathrm{Ar} /{ }^{39} \mathrm{Ar}$ age of $309 \pm 3 \mathrm{Ma}$ has been obtained on biotite from the thermal aureole of the Pont-de-Montvert granite (Monié et al. 2000).

The leucogranite (Signaux pluton) is subdivided into two subfacies according to its mineralogy: the cordierite-rich Laubies adamellite and the muscovite-bearing Finiels facies (Fig. 1). Local field observations of xenoliths and relative chronological relationships show that the porphyritic monzogranitic pluton of the Pont-de-Montvert-Borne intrudes the Signaux pluton (Van Moort 1966) (Fig. 1). However, the younger age of ca $303 \pm 3$ Ma recently obtained for the Finiels granite (U/Pb dating of monazite, Brichau et al. 2007) re-questions this hypothesis.

The Mont-Lozère-Borne massif is characterized by the occurrence of numerous granite, aplite and pegmatite dykes and sills widespread within and close to the Pont-de-Montvert and Borne plutons. A vertical N-S trending dykes network crosscut the eastern part of the Pont-deMontvert granite and likely the entire Borne body. Granite sill, centimeters to meter-thick aplitic and pegmatitic dykes are widespread within the contact aureole zone.

Six types of late Variscan hydrothermal occurrences have been described in the Cévennes area and are, from older to younger (Charonnat 2000) (Fig. 2a): (1) low-angle black shear zone (close to the monzogranite contact) and quartz-rich lenses with feldspar, tourmaline and chlorite; (2) low-angle cassiterite-wolframite-bearing quartz veins associated with aplitepegmatite dykes; (3) high-angle tourmaline veinlets, sometimes bearing sulfides, spatially associated with aplite-pegmatite; (4) high-angle lollingite-rich quartz breccia veins (up to $1.6 \mathrm{~g} / \mathrm{t} \mathrm{Au})$; (5) high-angle $\mathrm{N} 60^{\circ} \mathrm{E}$ trending $\mathrm{Au}-(\mathrm{Sb})$-bearing quartz veins that represent the 
main economic feature of the area; (6) gold-bearing quartz pebbles (Bulidou paleoplacer) occurring within the lower sedimentary unit of the Lower Stephanian Alès coal basin (Ahmadzadeh et al. 1986, Nomade et al. 1999).

\section{Description of representative structures}

Aplites, pegmatites, granites, and the six types of hydrothermal occurrences were collected for geochronology and stable isotope geochemistry performed during this study. In this chapter, the geometry, mineralogy, and chemistry of these objects will be presented and discussed. Their location is indicated in Figs. 1 and 2.

Granite, aplite, and pegmatite

The porphyritic Pont-de-Montvert-Borne monzogranite is characterized by few-centimetersized orthoclase surrounded by an aphanitic matrix with andesine, K-feldspar, biotite and quartz. $\mathrm{N}-\mathrm{S}$ trending, vertical aplite, and pegmatite dykes are intrusive within both the monzogranite and the hornfels micaschists (Fig. 2b, c). Mineralogically, aplites are constituted by quartz, damouritized plagioclase, and perthitic alkali feldspar, whereas pegmatites are characterized by two micas, quartz, plagioclase and perthitic K-feldspar assemblage. Few tourmaline and biotite minerals are observed within these rocks, sometimes within miarole texture. Cordierite is also represented. The aplite mineralogical assemblage appears very close to that of the pegmatite/aplite-pegmatite system, thus excluding a clear distinction between them. In fact, mutual relationships between aplite and pegmatite veins do not allow us to settle a relative chronology between them (Fig. 2b), except in the St-Melany $\mathrm{W}$-(Sn) occurrence (see location in Fig. 1). On this place, a network of $\mathrm{N}-\mathrm{S}$ trending, highangle dyke of aplite and pegmatite crosscut the micaschist foliation. Because aplites are crosscut by wolframite-bearing veins (type ii) and pegmatite cut one of these veins, we herein demonstrate the synchronicity between magmatism and hydrothermalism.

Tourmaline is observed within the two main facies of the Mont-Lozère massif (i.e., the Pontde-Montvert-Borne porphyritic monzogranite and the Signaux leucogranite) but only in the vicinity of the aplite dykes (Fig. 3). Within aplite and pegmatite, tourmaline is a good indicator of hydrothermalism since this mineral fills voids and "miaroles" or occurs as an interstitial phase (Fig. 3a, b). In aplite, tourmaline preferentially occurs as patches with muscovite, chlorite, apatite, and very fine grained titanium oxides, surrounded by hydrothermal albite-quartz corona (Fig. 3b). Tourmaline is never at equilibrium with the primary mineral phases such as magmatic biotite and cordierite. Within aplite veins crosscutting the granite, tourmaline is rare whereas in veins intruding micaschist, tourmaline preferentially develops along aplite rims and at the contact with the neighboring host-rock (Fig. 3c).

Low-angle hydrothermal structures (type i)

Two types of low-angle structures have been investigated. The first one corresponds to lowangle lenses associated with a discrete E-W trending stretching lineation (Fig. 4a). Their formation is suggested to occur during the late orogenic extensional collapse (Allemand et al. 1997; Charonnat et al. 1999). Mineralogically, the presence of tourmaline and K-feldspar allows these veins to be easily distinguished from the syn-folial quartz veins formed during thickening stages (Arnaud 1997). Their systematic association with discrete $\mathrm{E}-\mathrm{W}$ trending 
stretching lineation and extensional top-to-the-east shear are additional criteria for their distinction from the early quartz veins (Fig. 4a).

The second type of hydrothermal structure consists of low-angle black shear zones also associated with a discrete $\mathrm{E}-\mathrm{W}$ trending stretching lineation. They are subparallel to the regional foliation and oriented $\mathrm{N} 130-160^{\circ} \mathrm{E}$ with a low eastward dip (Figs. 2c, 4b). Drag folds and shear bands indicate top-to-the-east shearing. The existence of black layers enriched in organic matter has been suspected but not demonstrated. In fact, these black layers seem to be mainly due to the presence of Fe oxides that might result from intensive alteration along discrete fluid circulation zones.

High-angle tourmaline-rich veinlets (type iii)

These structures are essentially encountered close to the southern limit of the Pont-deMontvert granite. They are peculiar, steeply dipping veins, mainly filled by tourmaline and accessory quartz \pm Na-feldspar (Fig. 4c, Charonnat et al. 1999) and forming a N-S trending, regularly spaced, vein network (Fig. 2c). Vein composition varies from pegmatitic quartz \pm albite \pm apatite \pm tourmaline veins to pure tourmalinite veins. In spite of lack of striae, the association with vertical "en échelon" tension gashes, also filled by tourmaline, indicates a general normal motion along the veins (Charonnat et al. 1999). Tourmaline veins can occur parallel and close to some aplitic dykes (Figs. 2c, 4d). Vein frequency increases in the vicinity of the large aplite dyke in Le Travers cross-section (Fig. 2c). In that case, tourmaline veins are enriched in sulfides (mainly arsenopyrite). Sulfides are also abundant as impregnation within the surrounding micaschist. These two features, vein parallelism and sulfide appearance, rise the question of the possible synchronism for aplite and tourmalinerich vein formation.

Mineralized quartz veins (types iv, v, vi)

Three types of mineralization have been collected along a N20 ${ }^{\circ} \mathrm{E}$ trending corridor located south of the Pont-de-Montvert pluton (Fig. 1). From north to south, they are:

1. lollingite-Au-bearing vein (type iv) is observed in the eastern part of the Le Travers crosssection (Fig. 2c), as medium-angle dipping brecciated quartz vein (sample GH05b, Fig. 4e) (Charonnat 2000; Havard 1997). Its internal texture is complex and associates, from the base to the top, breccia, milky quartz, locally affected by subgrain polygonization and gouge formation certainly due to some late reworking. A normal motion toward the NW is herein defined. Close to the vein, hornfels contain disseminated sulfides (pyrrhotite, arsenopyrite), ilmenite, and biotite (65 ppb Au, 40,000 ppm As). An additional occurrence of the same type has been identified more to the west (Bougès vein) but not analyzed in detail.

2. Au-(Sb)-bearing quartz veins (type v, samples GH21, X9b, and X11b, Fig. 4f) are nearvertical, NE-SE trending and are located in the Alteyrac feldspar-bearing quartzite, which is one of the competent levels in the Cévennes micaschists: (Fig. 2a). These veins experienced a polyphase emplacement process responsible for their complex texture. They are common in the Variscan orogenic gold deposits in the French Massif central (Bouchot et al. 2005; Nomade et al. 1999). Their formation has been integrated in the late orogenic evolution of the Cévennes gold district, certainly during the later stages of the extensional tectonics widespread within this part of the Variscan Belt (Charonnat et al. 1999).

3. Sb-(Au)-bearing veins of the Collet de Dèze district, $10 \mathrm{~km}$ south of the Pont-de-Montvert 
monzogranite (sample Te2) (Ahmadzadeh et al. 1985) and a sample from the Terraillon deposit (sample X36b) have been collected and only analyzed for ${ }^{40} \mathrm{Ar} /{ }^{39} \mathrm{Ar}$

geochronology. These veins also appear in the core of a competent gneiss layer herein called the Apié volcano-sedimentary gneiss.

South of the Pont-de-Montvert-Borne pluton, the mineralization emplacement conditions change from North to South as follows. Loellingite-pyrrhotite-bearing quartz vein (type iv) with polygonization of hydrothermal quartz is a marker of high-temperature fluid and low $\mathrm{S}$ fugacity $\left(>300-350^{\circ} \mathrm{C}\right)$ (Barton and Skinner 1979). Arsenopyrite-gold-bearing veins (type v) indicate intermediate temperature according to fluid inclusion study $\left(340-150^{\circ} \mathrm{C}\right)$ (Nomade et al. 1999). Arsenopyrite-stibnite-bearing veins (also type v) are classically interpreted as witness of low temperature $\left(\sim 100^{\circ} \mathrm{C}\right)$ (Bril et al. 1994).

A few samples of gold-bearing pebbles from the Alès coal basin (type vi) and assumed to result from the erosion and sedimentation of the vertical mineralized quartz vein (type v) were also collected (samples BG4b and X6a).

Magmatic- and hydrothermal-related alteration within micaschist In the surrounding micaschist, the thermal metamorphism due to monzograntic intrusion and other magmatic features are expressed by the crystallization of biotite and white mica porphyroblasts frequently associated with top-to-the-east shearing. For instance, biotite forms pressure shadows around Ti-rich oxides, Fig. 5a). The alteration effects are mainly represented by the crystallization of tourmaline and by the transformation of biotite into chlorite. For example, within the low-angle black layers (type i) located south of the Pont-deMontvert granite, the metamorphic white micas are destabilised into yellow hydro-micas.

Generally, tourmaline abundance increases with the proximity of the contact with aplite (Fig. 3c), associated with the increase in chlorite, muscovite, apatite, and titanium oxides and the decrease in the metamorphic minerals of the micaschist, such as biotite. If the proportion of tourmaline and associated minerals clearly depends on the initial micaschist composition, tourmaline is more abundant within Al-rich micaschists (north of the Mont-Lozère plutonic complex) and more discrete within Al-poor micaschist (southern domain of the Pont-deMontvert granite). This tourmaline distribution is correlated with the large occurrence of numerous high-angle tourmaline extensional veins as described previously. One can suggest that, in this southern domain, tourmaline concentrates within these structures, thus explaining its lack within the micaschist except in the extreme vicinity of the high-angle tourmaline-rich veins (type iii) as the result of diffusion through foliation anisotropy (Figs. 3d, 4c). Moreover, the surrounding micaschist is frequently leached at the contact with veins and a white micarich zone can appear, likely as the result of a reaction front. This phenomenon is also associated with progressive mineral change within the matrix such as the transformation of biotite into chlorite close to the tourmaline-rich veins (Fig. 5c).

A generation of Ti oxide associated with the alteration process is recognized within the surrounding micaschist (Fig. 5b). In fact, Ti oxides and associated chlorite result from the breakdown of biotite and can partially preserve its crystallographic orientation. These $\mathrm{Ti}$ oxides crystallize after the early ones that occur as porphyroclasts surrounded by red biotite (Fig. 5a). SEM analysis reveals that the earlier oxides contain residual ilmenite (Fig. 5d) surrounded by complex inclusions composed by zircon, thorite, monazite, xenotime, yttrocolombite, and scheelite (Fig. 5e). 
Analytical methods

Mineral chemistry

Chemical composition has been determined with a Camebax Datanim electron microprobes of the CNRS-University of Orléans-BRGM group equipped with four wavelength-dispersive Xray spectrometers. Minerals were analyzed in polished thin sections. Operating parameters were $20 \mathrm{nA}$ bean current and a $15 \mathrm{kV}$ accelerating voltage.

\section{$\mathrm{H}, \mathrm{O}$ isotope geochemistry}

Tourmaline and quartz were separated by handpicking under a binocular for $\mathrm{H}$ and $\mathrm{O}$ isotope geochemistry. And $2 \mathrm{mg}$ of quartz and tourmaline was analyzed for oxygen isotope composition by laser-CO2 fluorination (Fouillac and Girard 1996). About 25-50 mg of tourmaline was extracted and analyzed for the hydrogen isotope geochemistry using the method of Bigeleisen et al. (1952); i.e., heating at $1,200^{\circ} \mathrm{C}$ and reduction of water on uranium at $800^{\circ} \mathrm{C}$. The obtained gases $\left(\mathrm{CO}_{2}\right.$ and $\left.\mathrm{H}_{2}\right)$ were analyzed for their isotopic compositions using a Delta $\mathrm{S}$ Finnigan-Mat gas-source mass spectrometer. The results are reported in $\delta$ units relative to international standard (SMOW for oxygen and hydrogen) (Table 1). Analytical reproducibility is about $\pm 0.3 \%$ for oxygen and $\pm 3 \%$ o for hydrogen.

${ }^{40} \mathrm{Ar} /{ }^{39} \mathrm{Ar}$ geochronology

Step-heating argon degassing was performed on mica single grains using a continuous argon laser probe with a beam diameter at least twice the grain size in order to achieve homogeneous heating. In addition, in situ laser probe analyses have been conducted on isolated grains using a focused laser beam that produced a crater of about $100 \mu \mathrm{m}$ in diameter and $20 \mu \mathrm{m}$ in depth. Micas were separated under the binocular after coarse rock crushing and cleaned with ethanol and distilled water. They were then irradiated with fast neutrons in the McMaster nuclear facility together with several MMHb flux monitors at $520.4 \pm 1.7 \mathrm{Ma}$ (Samson and Alexander 1987). After irradiation, the samples were placed on a Cu-holder inside a UHV chamber and baked at $200^{\circ} \mathrm{C}$ during $48 \mathrm{~h}$. The analytical device consists of (1) a multiline continuous $6 \mathrm{~W}$ argon laser; (2) divergent and convergent lenses for selection of beam diameter; (3) a small inlet line for extraction and purification of argon; (4) a MAP 21550 noble gas mass spectrometer. Each analysis involved $5 \mathrm{mn}$ for gas extraction and cleaning and $10 \mathrm{mn}$ for data acquisition. System blanks were evaluated every three analyses and yielded values close to $2.10^{-12} \mathrm{cc}$ for ${ }^{40} \mathrm{Ar}$ and $3.10^{-14} \mathrm{cc}$ for ${ }^{36} \mathrm{Ar}$. Ages and errors were calculated according to McDougall and Harrison (1988). Results are illustrated as age spectra and spot fusion age maps in Figs. 9 and 10. The quoted errors represent one sigma deviation. The uncertainty in the $\mathrm{J}$ parameter is only considered in the calculation of the plateau and total age errors.

\section{Mineral chemistry}

Biotite, white micas, tourmaline, Ti oxide, and apatite were analyzed in granites, aplites, hydrothermal occurrences and micaschists.

Biotite and white micas

The chemical composition of biotite and white micas contained within micaschists and magmatic rocks is represented within the $\mathrm{Al}_{\text {tot }} \mathrm{vs}$. $\mathrm{Fe}+\mathrm{Mg}+\mathrm{Ti}+(\mathrm{Si}-6)$ diagram of Guidotti (1984) (Fig. 6). The magmatic biotite, occurring as primary phase of the aplite, is located 
close to the annite-phlogopite pole, whereas red biotite of the Pont-de-Montvert granodiorite metamorphic aureole occurs within the eastonite domain, enriched in Al. All the white micas found within aplites and pegmatite collected north and south of the Mont-Lozère plutonic complex fall into the muscovite field (Fig. 6). The other white micas have been divided in two groups, one dealing with micas from micaschists and the other from tourmaline-rich veinlets of the Fig. 3b. For both groups, the analyses evolve from the muscovite field toward the phengitic one, traducing the effects of the phengitic substitution (Fig. 6).

\section{Tourmaline}

Chemical compositions of tourmaline are reported in the $\mathrm{Fe}-\mathrm{Al}-\mathrm{Mg}$ triangular diagram of Henry and Guidotti (1985), where they fall within the schörl-dravite field (Fig. 7). Tourmaline in aplite from Le Travers area (Fig. 2c) lies in the field of magmatic ferriferous tourmaline, whereas tourmaline from the granite and intrusive aplite-pegmatite located in the northern part of the Mont-Lozère plutonic complex (Fig. 2b) are slightly enriched in Mg. Tourmaline from high-angle veinlets of the Le Travers section (Fig. 4c) is also marked by a ferromagnesian composition (domain C, Fig. 7). Tourmaline in low-angle lenses and black shear zones (Fig. 4a, b) lies within the field of Al-undersaturated metamorphic rocks. Tourmaline in the high-angle veins (type iii) plots in the field of Al-saturated metapelite. Significant contents of $\mathrm{F}$ are measured in tourmaline of aplites and high-angle veins, the highest values being in tourmaline from aplites.

\section{Accessory minerals}

Apatite analyzed in aplites and high-angle tourmaline veinlets is a Mn-rich fluoro-apatite $(0.2-1.9 \mathrm{wt} \%$ of $\mathrm{MnO})$. Ti oxide associated with tourmaline within high-angle veinlets is rutile that shows some chemical zoning with tungsten-rich zones. Within the micaschist, we also found trace element-poor Ti oxide.

\section{$\mathrm{H}$, O isotope geochemistry \\ Studied material}

Two types of analysis were realized in this study. First, samples representative of the different petrographic facies of the Mont-Lozère-Borne plutonic complex were selected for bulk-rock oxygen isotopic analyses (Fig. 8a) in order to determine the origin of the granite complex. Second, samples of tourmaline veinlet (type iii), aplite, pegmatite, and selvage of pegmatite (sample CE71O) were selected for hydrogen isotope analyses on both quartz and tourmaline combined with oxygen isotope determination on quartz. Oxygen isotopic thermometry was applied on the tourmaline-quartz couple of the aplites and associated hydrothermal veins, in order to estimate their temperature of emplacement (Table 1). Finally, the $\delta^{18} \mathrm{O}$ and $\delta \mathrm{D}$ of the fluids in equilibrium with tourmaline were estimated using the $\delta^{18} \mathrm{O}$ and $\delta \mathrm{D}$ of tourmaline, the tourmaline-water oxygen fractionation (Clayton et al. 1972; Koetzer et al. 1993; Zheng 1993), the tourmaline-water hydrogen fractionation (Blamart et al. 1989; Koetzer et al. 1993) and the temperatures estimated with the isotopic thermometry.

\section{Results}

\section{Bulk-rock}


The bulk-rock $\delta^{18} \mathrm{O}$ values of granite range between +10 and $+14 \%$ SMOW, with a good reproducibility (Fig. 8b). The $\delta^{18} \mathrm{O}$ values of the porphyritic facies of the Pont-de-MontvertBorne granite yields lower values around $+10.5 \%$ SMOW. The $\delta^{18} \mathrm{O}$ values of the rocks corresponding to the Signaux leucogranite (i.e., the Bougès, Laubies and Finiels facies) range between +12 and $+14 \%$. The only $\delta^{18} \mathrm{O}$ value available for aplite shows a high value of $+13.5 \%$. The low $\delta^{18} \mathrm{O}$ value measured in a small-size leucocratic intrusion in the northern part of the Mont-Lozère plutonic complex (sample X182b) can be attributed to a partial weathering of the sample. Globally, the different facies of the Mont-Lozère granitic complex show high $\delta^{18} \mathrm{O}$ values consistent with granitoids dominantly derived from a crustal protolith (Fouillac and Rossi 1991; Lerouge et al. 2000; Rossi et al. 1988; Taylor 1980) in contradiction with some recent results that suggest a mixed crustal and mantle origin (Brichau et al. 2007).

\section{Mineral separate}

Seventeen samples of tourmaline, i.e., two from the low-angle quartz lenses, eight from the high-angle normal veins, four from the aplites, and three from the aplite-pegmatites and their selvage, were analyzed for their oxygen and hydrogen isotope composition (Table 1). The $\delta^{18} \mathrm{O}$ values of tourmaline are quite similar, ranging between +9 and $+10 \%$ with a lowest value close to $8 \%$ for the low-angle quartz-K-feldspar-tourmaline lens X156. The $\delta \mathrm{D}$ values of tourmaline show a large variation between -100 and $-33 \%$. $\delta \mathrm{D}$ values of tourmaline in aplites and hydrothermal veinlets are comparable and range between -100 and $-70 \%$. $\delta \mathrm{D}$ values of tourmaline from mineralized samples are quite close to -60 and $-50 \%$. The highest $\delta \mathrm{D}$ values $(-33$ to $-39 \%$ ) correspond to the samples of low-angle lenses (Table 1$)$.

Quartz $\delta^{18} \mathrm{O}$ was measured in ten samples, selected within aplites, low-angle lenses, highangle tourmaline veins, and gold-bearing quartz occurrences (Table 1). The quartz $\delta^{18} \mathrm{O}$ values in tourmaline-rich veins, low-angle quartz veins, and aplite range between +10.1 and $+12.4 \%$. Conversely, high-angle gold-bearing quartz lodes show high $\delta^{18} \mathrm{O}$ values ranging from +13.7 to $+17.5 \%$.

${ }^{40} \mathrm{Ar} /{ }^{39} \mathrm{Ar}$ geochronology

Analyzed samples

White mica from ten samples has been analyzed. Five samples are representative of the magmatic events (Fig. 9) whereas the others characterize the hydrothermal ones (Fig. 10).

Concerning the first group, three samples have been collected along a cross-section in the northern part of the Mont-Lozère granitic complex (Fig. 2b) and one close to the Le Travers locality, on the southern border of the massif (Fig. 2c). Each type of magmatic lithologies has been analyzed: i.e., aplite-pegmatite (sample CE71i), pegmatite (sample CE71c), granite (Finiels facies, sample CE71t) and aplite (sample CE50b). The last sample (CE70i) is the pegmatite collected within the Ste-Melany area, located east of the Borne monzogranite (Figs. 1, 9).

Most of the samples corresponding to hydrothermal features are quartz-rich mineralized veins. From north to south, sample GH05d comes from the Le Travers löllingite-bearing Au vein (Fig. 4e), samples GH21 and X11b have been collected within the Pont-de-Rastel and the Alteyrac veins, respectively. Both samples belong to the $\mathrm{Au}-(\mathrm{Sb})$ district of the Cévennes, and sample TE2 from the Teraillon Sb-(Au) district (see location in Fig. 1). 
Results

\section{Magmatic samples}

The two pegmatite samples CE71c and CE71i were analyzed using both step-heating and spot fusion techniques. The results point to similar ages close to $301 \mathrm{Ma}$ with errors of about $3 \mathrm{Ma}$, with little or no evidence of isotopic heterogeneity (Fig. 9a, c). Muscovite CE71c provides a well-defined plateau of $301.2 \pm 3.1$ Ma for $100 \%$ of the gas released, whereas eleven spot fusion ages obtained on CE71i range from 296.0 \pm 4.3 Ma to 305.0 $\pm 2.2 \mathrm{Ma}$. Spot fusion analyses were carried out on the Finiels-type granite (CE71t) and a related fine-grained aplite (CE50b). Muscovite CE71t give 15 apparent ages that scatter from 299.1 \pm 1.3 Ma to $309.9 \pm 4.7 \mathrm{Ma}$, with the majority of ages in the range 306-310 Ma (Fig. 9e), in agreement with the ages reported on Fig. 9d for muscovite CE50b. Ages younger than this range probably result from the degassing of a loosely bound argon component at the surface of the muscovite crystal or along cracks. The age spectrum corresponding to the Ste-Melany pegmatite is remarkably flat for $98 \%$ of the gas released with a plateau age of $306.5 \pm 3.1 \mathrm{Ma}$ (sample CE70i, Fig. 9b).

\section{Hydrothermal samples}

With the exception of a single spot fusion data, all ${ }^{40} \mathrm{Ar} /{ }^{39} \mathrm{Ar}$ ages obtained on hydrothermal white mica from the Le Travers quartz vein (sample GH05d) are bracketed between 303 and $306 \mathrm{Ma}$ (Fig. 10a). By contrast, white mica from the Pont-de-Rastel gold-bearing vein (sample GH21) provides older ages mainly in the range of 310-318 Ma, with no evidence of a systematic zoning from core to rim (Fig. 10b). Older ages were found from the Teraillon Sb( $\mathrm{Au}$ ) district (sample Te2) with results bracketed between 315 and $320 \mathrm{Ma}$ (Fig. 10d), whereas age around $307 \mathrm{Ma}$ is also found within these districts (sample X36b, Fig. 10e). By comparison, the white mica from the Alteyrac gold-bearing vein (sample X11b) has been stepwisely degassed by increasing regularly the power of the laser beam. The resulting age spectrum is discordant and can be divided into two domains (Fig. 10c). The first heating steps related to $40 \%$ of the gas released yield ages close to 300-305 Ma. Then, ages increase sharply to a second set of apparent ages that define a plateau of $313.5 \pm 2.5 \mathrm{Ma}$. Clearly, this indicates that the dated mica is a composite isotopic system resulting from the partial recrystallization of a 320-Ma-old muscovite, during the hydrothermal alteration at about 305 Ma.

Because the temperature of emplacement of Le Travers lollingite-quartz veins is close to the generally admitted closure temperature for argon in muscovite (about $400^{\circ} \mathrm{C}$, Hames and Bowring 1994), and because of relatively high cooling rates in upper crustal levels such as the Cévennes micaschists, concordant ages obtained on sample GH05d between 303 and $306 \mathrm{Ma}$ can be considered as the age of the Au-Sb mineralizing event in the Cévennes, contemporaneously with the emplacement of the Finiels granite dated at $303 \pm 3 \mathrm{Ma}$ on monazite (Brichau et al. 2007). On the other hand, the $306 \mathrm{Ma}$ age obtained on the pegmatite that is assumed to be coeval with the W-Sn-bearing vein of Ste-Melany argues for a synchronism between W-Sn and Au-Sb events in the Cévennes. The 303-306 Ma bracket is consistent with ages obtained at the scale of the French Massif Central between 310 and $300 \mathrm{Ma}$ (Bouchot et al. 2005).

Discussion

Geochronological data 
Because age results are homogeneous for all the aplite and pegmatite samples, we argue for the existence of a distinct magmatic event at ca. 301-306 Ma. This event could be related to the Finiel facies, part of the Signaux pluton (ca. $303 \mathrm{Ma}$ ), and differs from the emplacement of the Pont-de-Montvert-Borne massif supposed to occur at ca. $316 \mathrm{Ma}$ (Brichau et al. 2007; Mialhe 1980) with a cooling achieved at ca. 309 Ma (Monié et al. 2000). This assumption is confirmed by the recent age obtained for the Finiel facies (ca. 303 Ma, Brichau et al. 2007) but remain uncertain because cartographically, this granite is supposed to be older than the Pont-de-Montvert-Borne one (Fig. 1).

White mica ages from the Au-bearing hydrothermal structures range from 320 to $301 \mathrm{Ma}$ (Fig. 10), two age end-members that correspond to the two magmatic events. As suggested above, it is likely that the dated muscovites from these quartz veins originate from the Cévennes micaschists host-rock and experienced incomplete resetting during the hydrothermal event as suggested by the discordant age spectrum of sample X11b (Fig. 10c). By contrast, the well-defined age obtained for sample GH05d (high-temperature lollingitebearing vein of Le Travers) at ca. $305 \mathrm{Ma}$ was obtained on newly formed muscovite at the rim of the quartz vein.

Because of the good correlation between ages from hydrothermal features and the ones of the leucogranite dyke system formation (i.e. 301-306 Ma), we herein conclude to the existence, at this time, of a significant magmato-hydrothermal event within this part of the French Massif Central.

Temperatures of formation of magmatic and hydrothermal features

Formation temperatures were estimated using the quartz-tourmaline isotopic oxygen thermometry (Koetzer et al. 1993; Zheng 1993) (Table 1). The thermometry of Zheng (1993) gives systematically higher temperatures than those derived from Koetzer et al. (1993). In aplite and pegmatite dykes, temperature ranges between 550 and $720^{\circ} \mathrm{C}$. Highest temperatures $\left(640-720^{\circ} \mathrm{C}\right)$ are estimated for a quartz-tourmaline miarole (CE63c). The aplite samples $\mathrm{X} 60 \mathrm{~K}$ and $\mathrm{X} 216$ yield average temperatures of $550-625^{\circ} \mathrm{C}$, consistent with temperatures expected for the end of magma crystallization and a magmatic system that was active during a long time. The formation temperatures of the hydrothermal high-angle tourmaline-rich veinlets (CE44) are estimated around $400-500^{\circ} \mathrm{C}$. The quartz-tourmaline thermometer applied to low-angle quartz-tourmaline lenses gives temperatures between 450 and $595^{\circ} \mathrm{C}$ that are consistent with the high-grade metamorphism affecting the unit in which lenses were sampled.

Origin of the magmatism and hydrothermal fluids

Whole-rock isotopic determinations demonstrate that all facies attributed to the Signaux pluton (i.e. Laubies and Finiels facies) are grouped within a domain characterized by $\delta^{18} \mathrm{O}$ values close to +12 and $+14 \%$ SMOW (Fig. 8 b). The analyzed aplite also ranges within this domain. Conversely, the three points obtained on the porphyritic facies of the Pont-deMontvert-Borne granite yields lower values around $+10.5 \%$ SMOW (Fig. 8b). It is worth noting that, whatever the nature of the intrusion, the $\delta^{18} \mathrm{O}$ is higher than those of the classical orogen-related granite bracketed between +6 and $+7 \%$ sMOW. Because of their specific higher values, all the intrusions forming the Mont-Lozère plutonic complex present a crustal signature, showing that all these granitic magmas result from the melting of the continental crust without any mantle contamination. This conclusion needs to be taken with care because 
a recent study proposed a mixed origin (mantle-derived basic and lower crust acid magmas) for the Cévennes-related porphyroid granitoids (Brichau et al. 2007).

Isotopic compositions of fluids at equilibrium with quartz and tourmaline were calculated in aplites, pegmatites, mineralized and unmineralized hydrothermal veins. They are plotted in an $\delta^{18} \mathrm{O}$ versus $\delta \mathrm{D}$ diagram in which the main reservoirs such as seawater, meteoric waters, and juvenile magmatic waters are reported (Fig. 11). The metamorphic field is represented by the domain of isotopic compositions of fluids at equilibrium with the micaschist of the Châtaigneraie district that are equivalent to the Cévennes micaschist (Lerouge et al. 2000; Lerouge and Bouchot 2009). Fluids at equilibrium with aplite and pegmatite are magmatic fluids that are slightly ${ }^{18} \mathrm{O}$-enriched relative to juvenile magmatic waters because of the dominant crustal component. Fluids at equilibrium with low-angle quartz-rich lenses show isotopic compositions similar to metamorphic fluids. Hydrothermal fluids at equilibrium with barren high-angle tourmaline-rich veins are similar or close to the magmatic field associated with aplites, whereas hydrothermal fluids at equilibrium with mineralized high-angle tourmaline-rich veins are D-enriched. This D-enrichment may be interpreted as a mixing between magmatic fluids and metamorphic fluids or as magmatic fluids that isotopically exchanged with metamorphic host-schist. No isotopic oxygen or hydrogen data could indicate any significant meteoric component in these hydrothermal fluids.

\section{Fluid/rock interactions}

Hydrothermal alteration in the Cévennes is essentially characterized by the development of tourmaline associated with biotite, muscovite, chlorite, F-apatite, and titanium oxides. Tourmaline is present within all the lithologies of the Cévennes area (i.e., aplites, granite, and micaschist). Tourmaline is present in aplites and pegmatites, crystallized from the late magmatic fluids exsolved from crustal-derived leucogranitic magma, as shown by the oxygen isotopic data on bulk-rock. Tourmaline is widespread along the aplite/micaschist contact and in tourmaline-bearing veins crosscutting the micaschist, whereas this mineral is less developed or even absent along the contacts between aplite and granite. This suggests that tourmaline crystallization strongly depends on interactions between late magmatic fluid and micaschist. Iron, magnesium, and alumina in tourmaline essentially results from the breakdown of early $\mathrm{Fe}-\mathrm{Mg}$-rich aluminosilicates such as biotite and cordierite slightly present in monzogranites and leucogranites and abundant in the Cévennes micaschist. The texture observed in Fig. 5c is in agreement with the following reaction:

fluid + biotite $=$ tourmaline + muscovite + titanium oxides + chlorite The $\mathrm{XFe}$, the $\mathrm{Al}$ content and the $(\mathrm{O}, \mathrm{H})$ isotopic composition of hydrothermal tourmaline, intermediate between those of late magmatic tourmaline and those of rare metamorphic tourmaline, confirms the buffering of late magmatic fluids by micaschist (Fig. 7). The two types of rutile are also informative; elongated rutile associated with chlorite in aplite host-rocks and in veins directly resulted from the breakdown of previous Ti-rich metamorphic biotite, whereas interstitial Wrich rutile in high-angle tourmaline veinlets directly precipitated from mobile titanium provided by hydrothermal fluids (Fig. 5e).

Conclusion: occurrence of hydrothermal event related to magmatism within the southern French Massif Central

Coeval with nappe stacking in the para-autochthonous unit at 345-340 Ma, the Cévennes micaschists experienced several episodes of crustal melting. The earliest one is represented by 
migmatite formation exposed north of the Mont-Lozère pluton (Faure et al. 2001). This first event is dated at ca. 330-325 Ma (Bé Mezémè et al. 2005, 2006). The second magmatic episode corresponds to the emplacement, at 320-315 Ma, of the Pont-de-Montvert-Borne granite and the formation of low-angle barren quartz-K-feldspar-tourmaline lenses, widespread within host-rocks (Arnaud 1997).

Around 306-301 Ma, a leucogranitic episode and its aplite-pegmatite swarm developed within the Pont-de-Montvert-Borne pluton and near its contact with hornfels. Actually, we can only affirm that this event is expressed by dike systems (this study). However, we suppose that the Finiels-muscovite granite can be an expression of this event as discussed above and even if this appears inconsistent with the cartographic constraints. Later, in the vicinity of the plutons, pneumatolitic fluids were expelled and precipitated as (1) miarole within leucogranite, (2) tourmaline-rich veinlets spatially related with aplite, and (3) scheeliteor wolframite-bearing veins. In the same period, Au-Sb-bearing veins were emplaced. As discussed above, they can develop $15 \mathrm{~km}$ far from the pluton (low-temperature Collet de Dèze $\mathrm{Sb}$-( $\mathrm{Au})$-veins), $5 \mathrm{~km}$ (intermediate-temperature Altayrac and Pont-de-Rastel Au-(Sb)-veins) or close to the pluton (high-temperature lollingite-Au vein of Le Travers). These mineralized outcrops are aligned within a N-NE trending corridor as illustrated in Fig. 1.

It is thus herein suggested that a magmatic-hydrothermal event affected the southern part of the French Massif Central between 306 and $301 \mathrm{Ma}$, around pre-existing granitic plutons emplaced at $315 \mathrm{Ma}$. A similar event has been also documented in the La Châtaigneraie district, more to the north, at ca. $306 \mathrm{Ma}$ (Lerouge and Bouchot 2005, 2009; Monié et al. 2000). The similitudes between Les Cévennes and Chataigneraie district are (1) occurrence of two successive and spatially associated magmatic events (porphyritic granite at $315 \mathrm{Ma}$ followed by leucogranite and aplite-pegmatitic expression at $305 \mathrm{Ma}$ ) and (2) characterization of a leucocratic magmatic system genetically connected to tourmaline-rich hydrothermalism. However, the La Châtaignerie district contains numerous W concentrations, whereas in the Cévennes area, $\mathrm{W}$ only appears as disseminations around the Mont-Lozère-Borne pluton and the only significant deposit is observed in the Ste-Melany area.

Long-lived magmatic event has been frequently proposed to be at the origin of any kind of hydrothermalism and mineralization within orogenic belts. However, the Cévennes exceptionally exhibits the co-existence of two coeval hydrothermal systems, B-W-(Sn) and As-Au-Sb ones, until now assumed to be unconnected (Bouchot et al. 2005). Two possibilities are suggested to explain this specificity.

\section{Hypothesis 1}

The B-W-(Sn) system was restricted around the Pont-de-Montvert-Borne pluton and an As$\mathrm{Au}-\mathrm{Sb}$ system, devoid of boron, developed under structural control within the N-NE trending corridor (e.g., Charonnat et al. 1999). In this case, the Le Travers outcrop, belonging to the As-Au-Sb system and containing lollingite mineral, represents an unusually high-temperature deposit in this kind of system. It can be explained by the thermal effect due to the proximity with the B-W-Sn hot magmato-hydrothermal system $\left(415-480^{\circ} \mathrm{C}\right.$, Table 1$)$. This interference between the two systems may also account for the complete reset of the Ar isotopic system in muscovite of the Le Travers occurrence.

Hypothesis 2

All hydrothermal expressions were linked to the same source but their distribution resulted from a structural zoning with respect to the granitic plutons. The B-W-(Sn) system represents the proximal end-member expression encountered in the close vicinity of the granite and 
records the magmatic signature (our study). Far away, the As-Au-Sb system emplaced under the structural control of the NW-SE extension in the N-NE trending corridor and reflected a $\mathrm{N}-\mathrm{S}$ trending thermal gradient. These deposits can then be assimilated to the distal expression of the same hydrothermal system.

Whatever the right explanation, it has been herein demonstrated that the hydrothermal event responsible for the formation of the Cévennes mineralizations was spatially and genetically associated with the 301-306-Ma-old leucogranitic magmatic event, thus providing an additional example of granite-related mineralization developed in orogenic context (e.g., Goldfarb et al. 2001; Groves et al. 1998).

Acknowledgments The GéoFrance 3D program through BRGM, Ministry of Education and CNRS-INSU funds supported this study. Additional financial support from the CNRS-GDR TRANSMET was provided in order to achieve this study. J.P. Milesi is strongly acknowledged for his constant support and fruitful discussions.

\section{References}

Ahmadzadeh H, Turc R, Picot P, Rochette JM (1985) Présence d'or dans certaines minéralisations antimonifères de la région du Collet de Dèze (Lozère): concession de Teraillon, 110ème Congrès National des Sociétés Savantes, pp 129-140

Ahmadzadeh H, Picot P, Legendre O, Marcoux E (1986) Caractérisation des minéralisations aurifères des Cévennes (Massif Central, France) dans leur environnement géologique. Doc BRGM 158:527563

Allemand P, Lardeaux JM, Dromart G, Ader M (1997) Extension tardi-orogénique et formation des bassins intracontinentaux: le bassin stéphanien des Cévennes. Geodin Acta 10:70-80

Arnaud F (1997) Analyse structurale et thermo-barométrique d'un système de chevauchements varisque : les Cévennes centrales (Massif central français)-Microstructures et mécanismes de déformation dans les zones de cisaillement schisteuses., $\mathrm{PhD}$ thesis, Institut National Polytechnique de Lorraine, Nancy, France, 266 p

Autran A, Cogné JP (1980) La zone interne de l'orogenèse varisque dans l'ouest de la France et sa place dans le développement de la chaîne hercynienne, Géologie de l'Europe du précambrien aux bassins sédimentaires post-hercyniens, 26e CGI. Ann Soc Geol Nord, Lille, pp 90-111

Barton PB, Skinner BJ (1979) Sulfide mineral stabilities. In: Barnes HL (ed), Geochemistry of hydrothermal ore deposits. Wiley, New York, pp 278-403

Bé Mezémè E, Cocherie A, Faure M, Legendre O, Rossi P (2005) In situ chemical dating of superimposed tectonic and magmatic events in the French Variscan Belt. Terra Nova 17:420-426

Bé Mezémè E, Faure M, Cocherie A, Chen Y (2006) Electron microprobe monazite geochronology: a tool for evaluating magmatic age domains. Examples from the Variscan French Massif Central. Lithos $87: 276-288$ 
Bigeleisen J, Perlman ML, Prosse RH (1952) Conversion of hydrogenic materials to hydrogen for isotopic analysis. Anal Chem 24:1356

Blamart D, Pichavant M, Sheppard SMF (1989) Détermination expérimentale du fractionnement isotopique $\mathrm{D} / \mathrm{H}$ entre tourmaline et eau à $600,500^{\circ} \mathrm{C}$ et $3 \mathrm{kbar}$. C R Acad Sci Paris 308:39-44

Bouchot V, Milési JP, Lescuyer JL, Ledru P (1997) Les minéralisations aurifères de la France dans leur cadre géologique autour de $300 \mathrm{Ma}$. Chron Rech Min 528:13-62

Bouchot V, Ledru P, Lerouge C, Lescuyer JL, Milesi JP (2005) Late Variscan mineralizing systems related to orogenic processes: The French Massif. Ore Geol Rev 27:169-197

Brichau S, Respaut JP, Monié P (2007) New age constraints on emplacement of the Cévenol granitoids, South French Massif Central. Int J Earth Sci, doi:10.1007/s00531-007-0187-x

Bril H, Marignac C, Cathelineau M, Tollon F, Cuney M, Boiron MC (1994) Metallogenesis of the french Massif Central : time-space relationships between ore deposits and tectono-magmatic events. In: Keppie JD (ed), Pre-Mesozoic Geology in France and related areas. Springer, pp 379-402

Brouder P (1963) Description d'une succession lithologique avec niveaux-repères dans les schistes cristallins des Cévennes près de Villefort (Lozère). Bull Soc Geol Fr 7:828-834

Charonnat X (2000) Les minéralisations aurifères tardi-hercyniennes des Cévennes (Massif central français). Cadre structural, gîtologie et modélisation 3D, Thèse d'Université, Université d'Orléans, Orléans, France, 260 p

Charonnat X, Chauvet A, Faure M (1999) Contexte structural des minéralisations aurifères tardihercyniennes des Cévennes (Massif central français). C R Acad Sci Paris, Sciences de la terre et des planètes 328:463-469

Clayton RN, O’Neil JR, Mayeda TK (1972) Oxygen isotope exchange between quartz and water. J Geophys Res 77:3057-3067

Faure M (1995) Late orogenic carboniferous extensions in the Variscan French Massif Central.

Tectonics 14:132-153

Faure M, Leloix C, Roig JY (1997) L'évolution polycyclique de la chaîne hercynienne. Bull Soc Geol Fr 168:695-705

Faure M, Charonnat X, Chauvet A (1999) Schéma structural et évolution tectonique du domaine paraautochtone cévenol de la chaîne hercynienne (Massif central français). C R Acad Sci Paris, Sciences de la terre et des planètes 328:401-407

Faure M, Charonnat X, Chauvet A, Chen Y, Talbot JY, Martelet G, Courrioux G, Monié P, Milesi JP (2001) Tectonic evolution of the Cévennes para-autochtonous domain of the Hercynian French Massif 
Central and its bearing on ore deposits formation. Bull Soc Geol Fr 172:687-696

Faure M, Bé Mezémè E, Duguet M, Cartier C, Talbot JY (2005) Paleozoic tectonic evolution of medio-Europa from the example of the French Massif Central and Massif Armoricain. In: Carosi R, Dias R, Iacopini D, Rosenbaum G (eds), The southern Variscan belt, Journal of the Virtual Explorer, Electronic Edition, ISSN 1441-8142, 19, 5

Fouillac AM, Girard JP (1996) Laser oxygen isotope analysis of silicate/oxide grain separates: evidence for a grain size effect? Chem Geol 130:31-54

Fouillac AM, Rossi P (1991) Near-solidus 180 depletion in a Ta-Nb-bearing albite granite: the Beauvoir granite, France. Econ Geol 86:1704-1720

Goldfarb RJ, Groves DI, Gardoll S (2001) Orogenic gold and geologic time: a global synthesis. Ore Geol Rev 18:1-75

Groves DI, Goldfarb RJ, Gebre-Mariam M, Hagemann SG, Robert F (1998) Orogenic gold deposits: a proposed classification in the context of their crustal distribution and relationship to other gold deposit types. Ore Geol Rev 13:7-27

Guerangé-Lozes J, Pelet J (1990) Carte géologique de France au 1/50000 feuille Génolhac. BRGM, Orléans

Guidotti CV (1984) Micas in metamorphic rocks. Rev Mineral 13:357-468

Hames WE, Bowring SA (1994) An empirical evaluation of the argon diffusion geometry in muscovite. Earth Planet Sci Lett 124:161-167

Havard ML (1997) Les minéralisations filonniennes à Au-As (Plomb) des régions des Cévennes et de la Châtaigneraie (Massif Central français). Caractérisation isotopique ( $\mathrm{Pb})$. Rôle minéralisateur des granites dans la mise en place de ces minéralisations, Master, Université de Montpellier 2, Montpellier, France, $58 \mathrm{p}$

Henry DJ, Guidotti CV (1985) Tourmaline as a petrogenetic indicator mineral : an example from the staurolite-grade metapelites of NW Maine. Amer Mineral 70:1-15

Koetzer TG, Kyser TK, King RW, Kerrich R (1993) An empirical oxygen- and hydrogen-isotope geothermometer for quartz-tourmaline and tourmaline-water. Geoch Cosmochim Acta 57:3421-3426

Laumonier B, Marignac C, Cheilletz A, Macaudière J (1991) Relations entre tectoniques superposées, migmatisations et mise en place des granites sur l'exemple de la bordure sud du dôme du Velay (Région de Laviolle, Ardèche, France). C R Acad Sci Paris 313:937-944 
Ledru P, Lardeaux JM, Santallier D, Autran A, Quenardel JM, Floc'h JP, Lerouge G, Maillet N, Ploquin A (1989) Où sont les nappes dans le Massif central français? Bull Soc Geol Fr 8(V):605-618

Lerouge C, Bouchot V (2005) Châtaigneraie-example of a late Variscan tungsten district, Southern French Massif Central: Lat. $44^{\circ} 40^{\prime}$ N, long. $2^{\circ} 35^{\prime}$ E. Ore Geol Rev 27:200-201

Lerouge C, Bouchot V (2009) Conditions of formation and origin of fluids for quartz-tourmaline veins in the La Châtaigneraie tungstiferous district (Massif Central, France): fluid inclusions and stable Isotopes. Bull Soc Geol Fr 180(3):263-270

Leruge C, Bouchot V, Guerrot C (2000) Fluids and the W (+As, Au) ore deposits of the EnguialèsLeucamp district, La Chätaigneraie, French Massif Central. J Geoch Explor 69-70:343-347

Marignac C, Cuney M (1999) Ore deposits of the French Massif Central: insight into the metallogenesis of the Variscan collision belt. Miner Deposita 34:472-504

Matte P (1986) Tectonics and plate tectonics model for the Variscan belt of Europe. Tectonophysics 126:329-374

McDougall I, Harrison TM (1988) Geochronology and thermochronology by the 40Ar/39Ar method. Oxford University Press, New York

Mialhe J (1980) Le massif granitique de la Borne (Cévennes). Etude pétrographique, géochimique, radiochronologique et structurale, 3ème cycle, Université Clermont Ferrand, $171 \mathrm{p}$

Monié P, Respaut JP, Brichaud S, Bouchot V, Faure M, Roig J (2000) 40Ar/39Ar and U-Pb geochronology applied to $\mathrm{Au}-\mathrm{W}-\mathrm{Sb}$ metallogenesis in the Cévennes and Châtaigneraie districts (Southern Massif Central, France). In Geode-GéoFrance3D workshop on orogenic gold deposits in Europe, with emphasis on the Variscides. Doc BRGM 297:77-79

Nomade S, Chauvet A, Barbanson L, Charonnat X (1999) Les minéralisations aurifères des Cévennes (Massif central français) : étude comparative des filons d'Alteyrac/Pont-de-Rastel et du paleoplacer du bulidou. C R Acad Sci Paris, Sciences de la terre et des planètes 328:815-822

Paris F, Robardet M (1990) Early Paleozoic paleobiogeography of the Variscan regions.

Tectonophysics 177:193-213

Pichavant M (1993) Anatexie crustale et volcanisme. Mém Soc Geol Fr 163:139-146

Roig JY, Calcagno P, Bouchot V, Maluski H, Faure M (1997) Modélisation 3D du paléochamp hydrothermal As + Au (330-300 Ma) le long de la Faille d'Argentat (Massif Central français). Chron Rech Min 528:63-69

Rossi P, Cocherie A, Meyer G, Fouillac AM, Autran A (1988) Metallogenic W and Sn granites : genesis and main distinguishing features, Mineral Deposits within the European Community, Society 
for Geology Applied to Mineral Deposits, Special Publication, pp 3-28

Sabourdy G, Berthelay JC (1977) Premiers résultats de l'étude géochimique des granites grenus à biotite et à deux micas du Mont Lozère (Massif Central français). Bull Soc Geol Fr 5:255-258

Samson SD, Alexander EC (1987) Calibration of the interlaboratory (super 40) Ar-(super 39) Ar dating standard, MMhb-1. Chem Geol 66:34-37

Taylor HP (1980) The effects of assimilation of country rocks by magmas on $18 \mathrm{O} / 16 \mathrm{O}$ and $87 \mathrm{Sr} / 86 \mathrm{Sr}$ systematics in igneous rocks. Earth Planet Sci Lett 47:243-254

Van Moort J (1966) Les roches crystallophylliennes des Cévennes et les roches plutoniques du Mont Lozère. Annales de la Faculté des Sciences de l'Université de Clermont 31:1-272

Williamson BJ, Shaw A, Downes H, Thirlwall MF (1996) Geochemical constraints on the genesis of hercynian two-mica leucogranites from the Massif Central, France. Chem Geol 127:25-42

Zheng YF (1993) Calculation of oxygen isotope fractionation in hydroxyl-bearing silicates. Earth Planet Sci Lett 120:247-263 
Figures

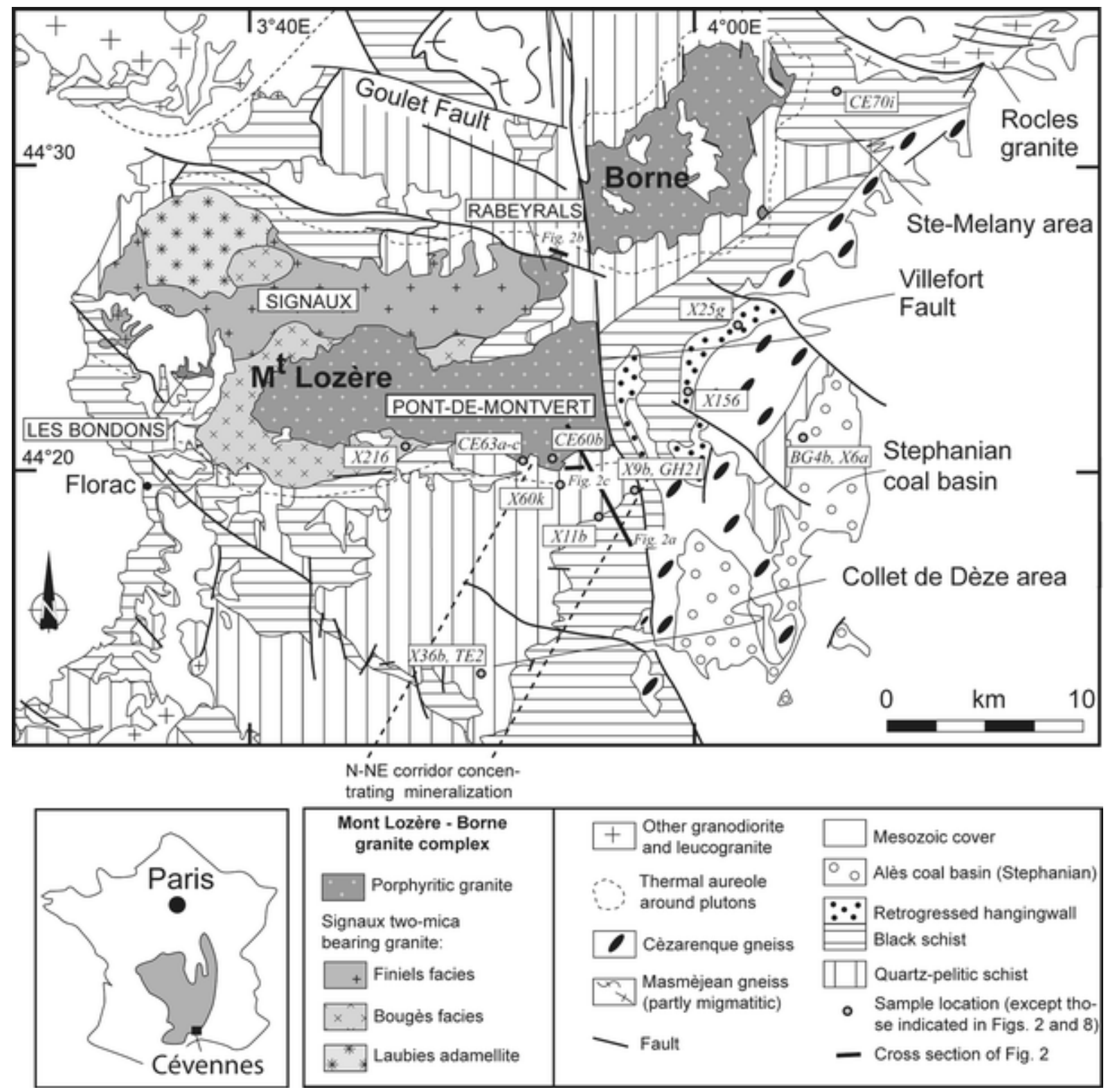

Fig. 1 Simplified map of the Cévennes area (modified after Faure et al. 2001). The different facies of the Mont-Lozère-Borne plutonic complex are particularly represented such as the location of the general (Fig. 2a) and detailed (Fig. 2b, c) cross-sections. Position of all samples collected for this study is also marked except for those indicated in Figs. 2 and 8 

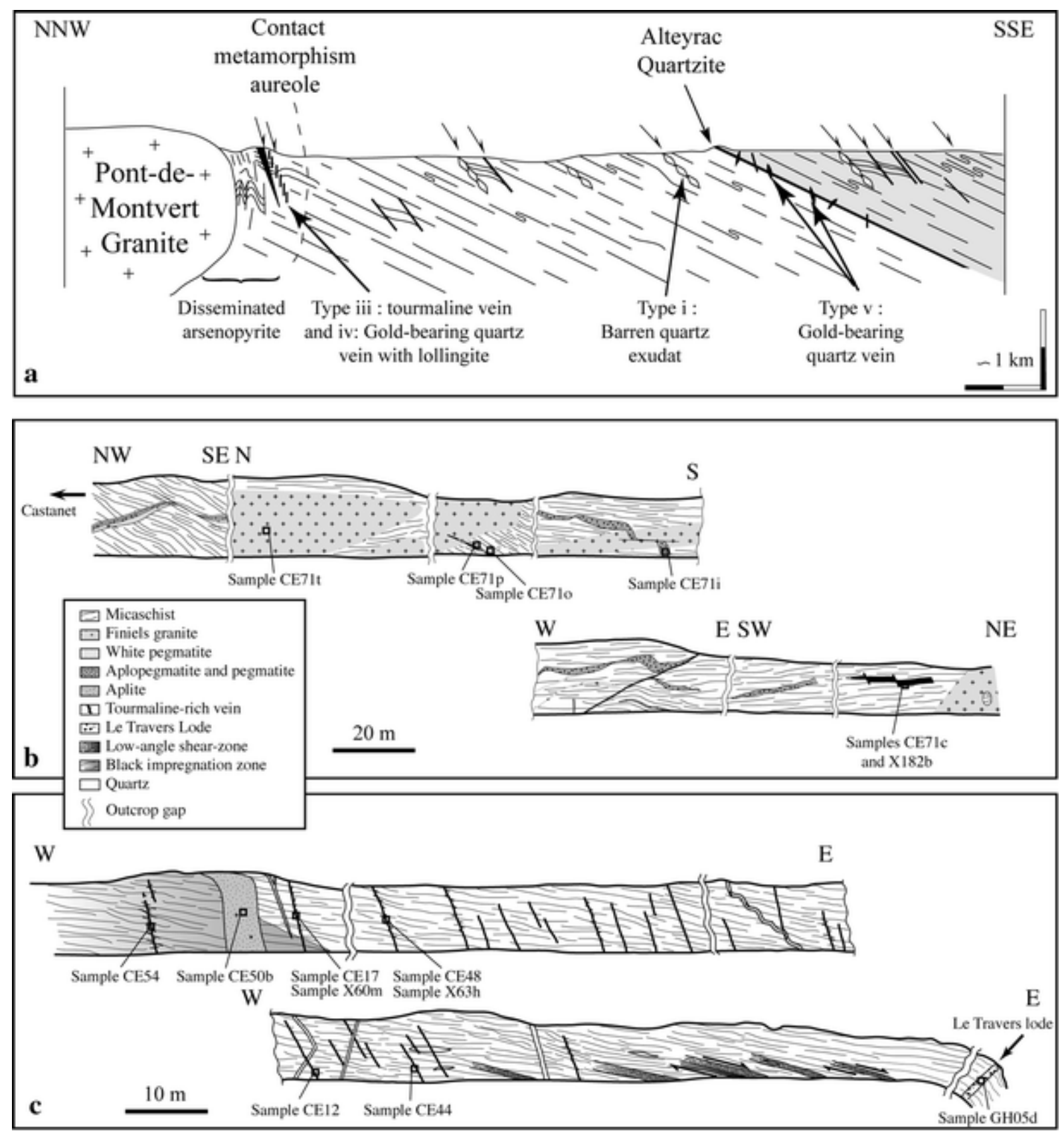

Fig. 2 a Synthetic NW-SE cross-section showing the relationships between all the units of the Cévennes area and the place of the hydrothermal structures. b Relationships between host-rock, aplite, and pegmatite north of the Mont-Lozère granitic complex. $\mathbf{c}$ Outcrop succession along the Le Travers cross-section, south of the Pont-de-Montvert granite 

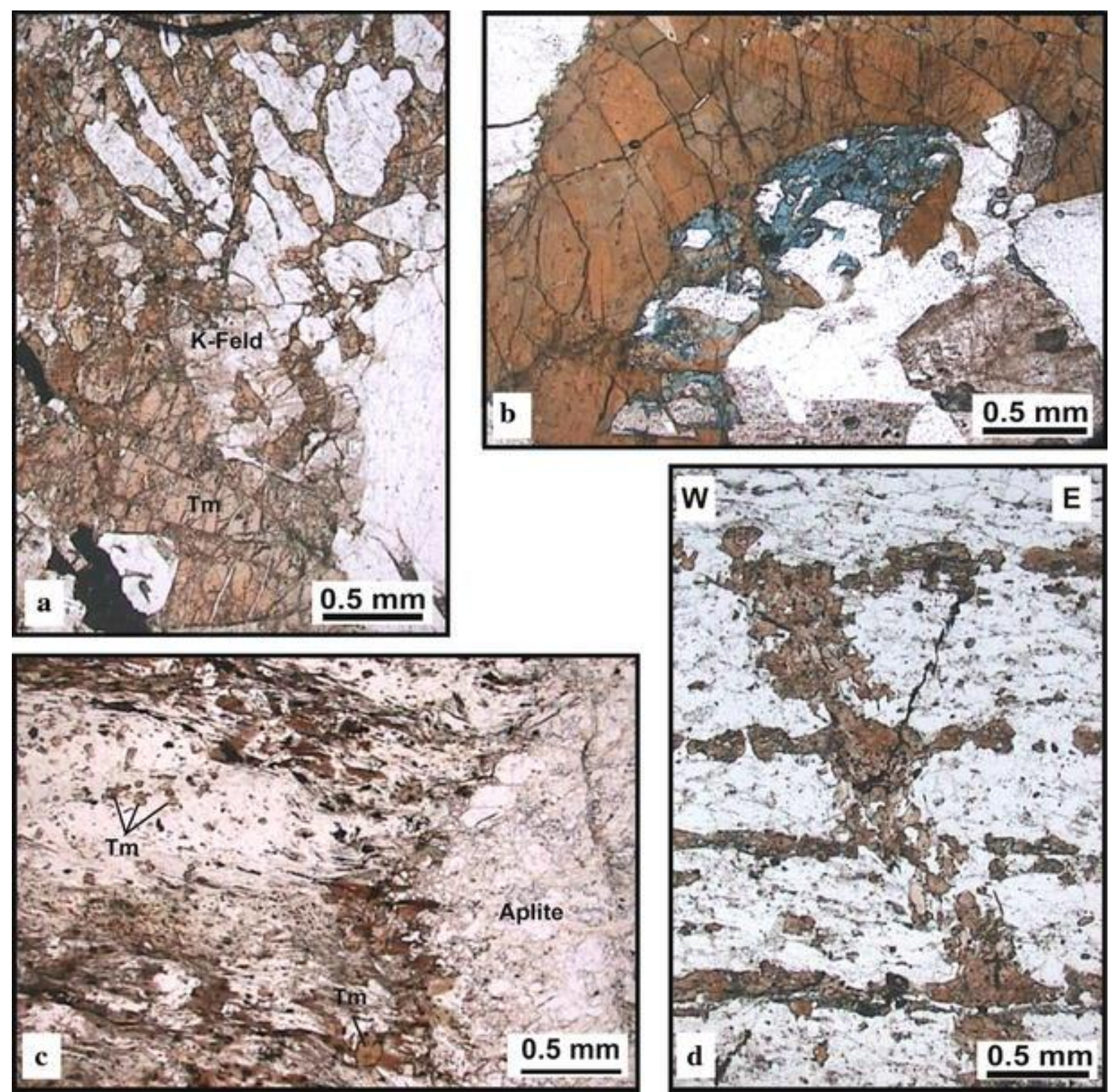

Fig. 3 Microscopic occurrence of tourmaline within the Cévennes area. $\mathbf{a}$ and $\mathbf{b}$ Tourmaline-rich miarole within pegmatite or granite. $\mathbf{c}$ Dissemination and increase of tourmaline close to an aplite dyke. d Tourmaline grains within high-angle dipping vein along the Le Travers cross-section. Note the diffusion of tourmaline within host-rock foliation. $K$-feld potassic feldspar, $T m$ tourmaline 

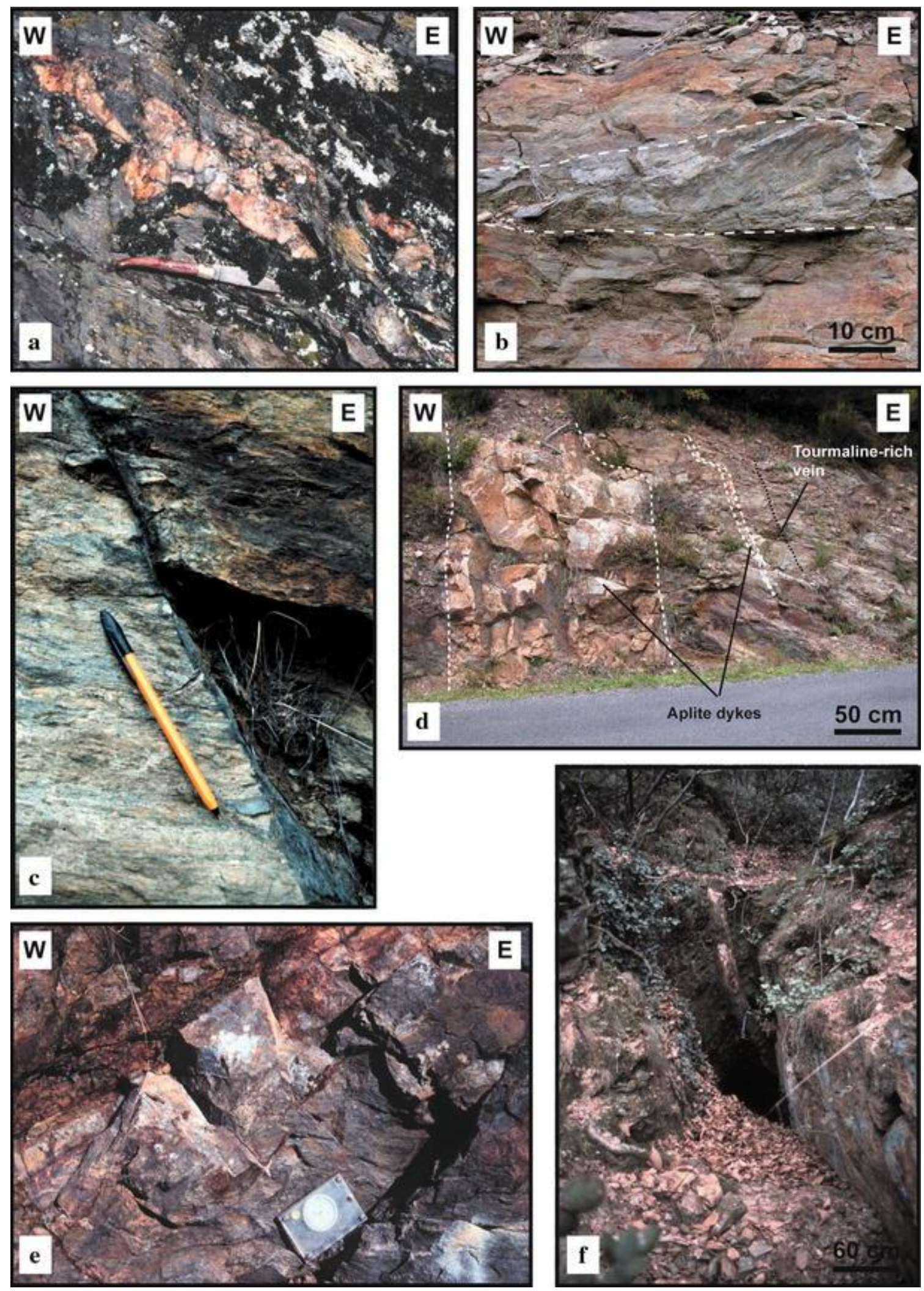

Fig. 4 Photographs of the hydrothermal features found within the Cévennes area. a Low-angle quartzK-feldspar-tourmaline lens associated with top-to-the-east shearing. b Low-angle black shear zone with top-to-the-east kinematics. $\mathbf{c}$ High-angle dipping tourmaline-rich veins. $\mathbf{d}$ Parallelism between tourmaline and aplite veins. e Lollingite-bearing quartz lode of Le Travers. $\mathbf{f}$ View of the gold-bearing Alteyrac quartz vein. Note the near-vertical dip 

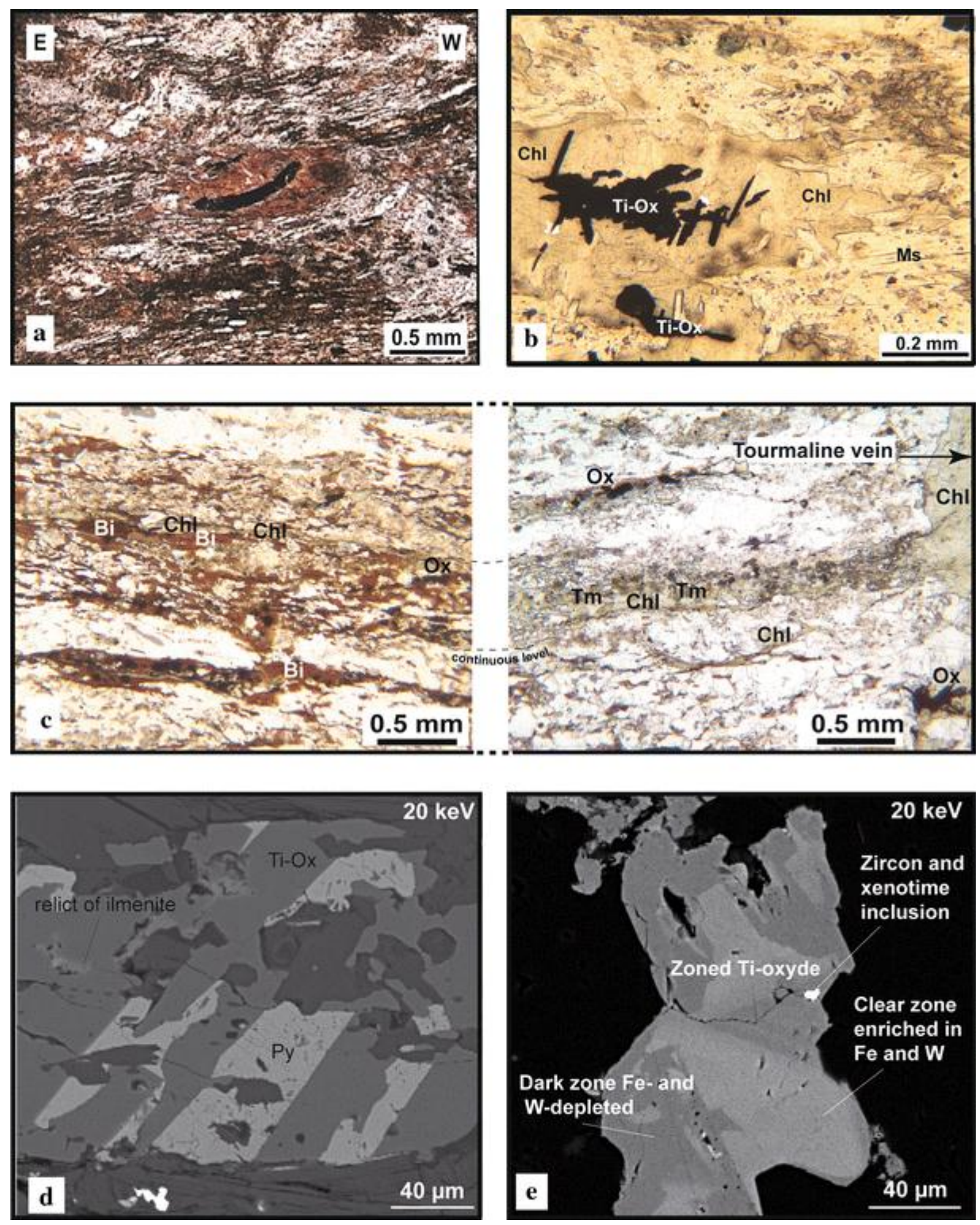

Fig. 5 a Biotite development around ilmenite indicator of top-to-the-east kinematics within the southern contact metamorphic aureole of the Pont-de-Montvert pluton. b Ti oxides and chlorite crystallizing within pressure shadows. $\mathbf{c}$ Mineralogical evolution at the vicinity of a high-angle tourmaline-rich vein (see text for explanation). d Detailed view of an oxide crystal showing relic of ilmenite and the association between Ti oxide and pyrite (SEM view). e SEM view showing the internal texture of Ti oxide including zircon and xenotime grains. $\mathrm{Chl}$ chlorite, $\mathrm{Ti}$ - $\mathrm{Ox}$ titane-rich oxide, $M s$ muscovite, $B i$ biotite, $O x$ oxide, $T m$ tourmaline, $P y$ pyrite, Fe: iron, $W$ wolfram 
Table $1(\mathrm{H}, \mathrm{O})$ isotopic data from the magmatic and hydrothermal features of the Cévennes area

\begin{tabular}{|c|c|c|c|c|c|c|}
\hline & Sample & Comment & $\begin{array}{l}\delta \mathbf{O}^{18} \\
\text { quartz } \\
(\%)\end{array}$ & $\begin{array}{l}\delta \mathrm{O}^{18} \\
\text { tourmaline } \\
(\%)\end{array}$ & $\begin{array}{l}\delta \text { D } \\
\text { tourmaline } \\
(\%)\end{array}$ & $\begin{array}{l}\text { Calculated } \\
\text { temperature } \\
\left({ }^{\circ} \mathrm{C}\right)\end{array}$ \\
\hline \multirow{2}{*}{ Aplite-pegmatite } & CE71p & $\begin{array}{l}\text { Within micaschist, with } \\
\text { tourmaline-rich core }\end{array}$ & - & - & -57 & - \\
\hline & $\mathrm{X} 182 \mathrm{~b}$ & $\begin{array}{l}\text { Within micaschist, with } \\
\text { tourmaline-rich core }\end{array}$ & - & 88 & -60.0 & - \\
\hline $\begin{array}{l}\text { Pegmatite host- } \\
\text { rock }\end{array}$ & CE71o & $\begin{array}{l}\text { Link with tourmaline } \\
\text { development in schist, } \\
\text { with sulfide }\end{array}$ & - & 10.0 & -75 & - \\
\hline \multirow{4}{*}{ Aplite } & CE60b & $\begin{array}{l}\text { With biotite and } \\
\text { sulfides }\end{array}$ & 10.1 & 9.1 & -82 & - \\
\hline & X60k & $\begin{array}{l}\text { With biotite and } \\
\text { sulfides }\end{array}$ & 11.6 & 9.7 & -78.0 & $550-625$ \\
\hline & $\mathrm{X} 216$ & $\begin{array}{l}\text { In core of porphyroid } \\
\text { granite }\end{array}$ & 11.5 & 9.8 & - & $600-675$ \\
\hline & CE63c & Within aplite & 12.2 & 10.6 & -75 & $640-720$ \\
\hline \multirow{2}{*}{$\begin{array}{l}\text { Low-angle quartz } \\
\text {-K-felspar-Tm } \\
\text { lens (type i) }\end{array}$} & $\mathrm{X} 25 \mathrm{~g}$ & Within micaschist & 11.5 & 9.5 & -39.0 & $515-595$ \\
\hline & $\mathrm{X} 156$ & Within micaschist & 10.3 & 80 & -33.0 & $450-522$ \\
\hline \multirow{8}{*}{$\begin{array}{l}\text { Tm-rich vein } \\
\text { (type iii) }\end{array}$} & CE12 & Within micaschist & - & 9.2 & -82.0 & - \\
\hline & CE44 & Within micaschist & 124 & 99 & -84 & $415-480$ \\
\hline & CE48 & Within micaschist & - & 9.3 & -73 & - \\
\hline & CE54 & Within micaschist & - & 9.8 & -100 & - \\
\hline & CE63a & Within aplite & - & 9.8 & -71 & - \\
\hline & CE17 & $\begin{array}{l}\text { Containing } \\
\text { arsenopyrite and within } \\
\text { schist }\end{array}$ & - & 9.8 & -50 & - \\
\hline & $\mathrm{X} 60 \mathrm{~m}$ & With sulfides & - & 9.6 & -50.0 & - \\
\hline & X63h & With sulfides & - & 10.4 & -55.0 & - \\
\hline \multirow{3}{*}{$\begin{array}{l}\text { Gold-bearing } \\
\text { quartz vein (type v } \\
\text { and vi) }\end{array}$} & BG4b & Mineralized pebble & 14.7 & - & - & - \\
\hline & X6a & Mineralized pebble & $\begin{array}{l}15.1- \\
17.5\end{array}$ & - & - & - \\
\hline & $\mathrm{X} 9 \mathrm{~b}$ & Ponl-de-Rastel vein & 13.7 & - & - & - \\
\hline
\end{tabular}




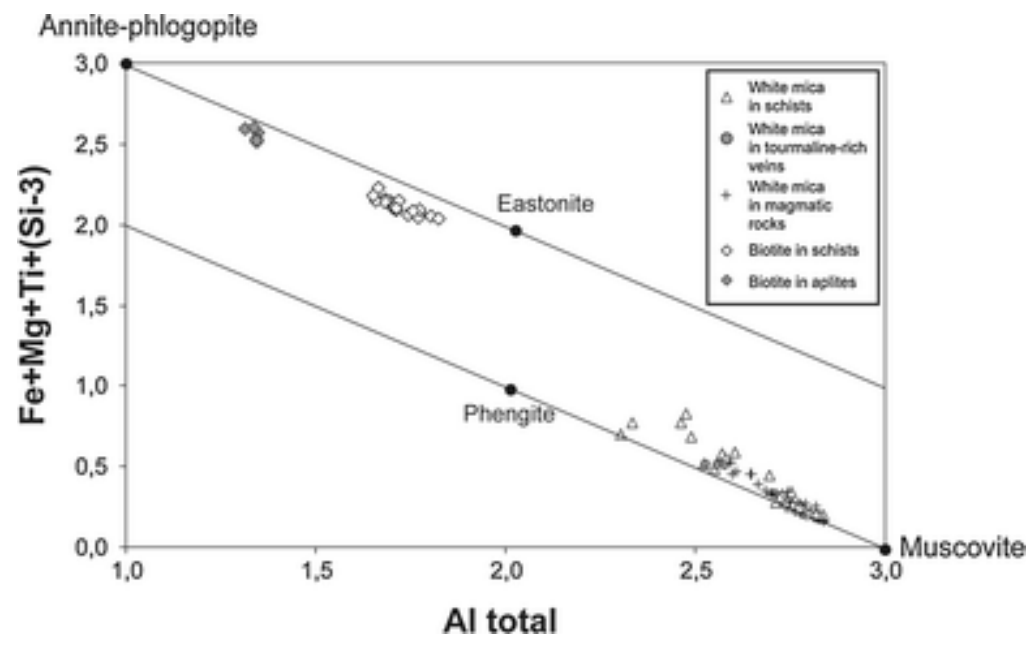

Fig. 6 Chemical composition of white and black micas of hydrothermal, micaschist and magmatic features of the Cévennes area plotted in an Al total vs Fe2 + Mg + Ti + (Si-6) diagram (Guidotti 1984)

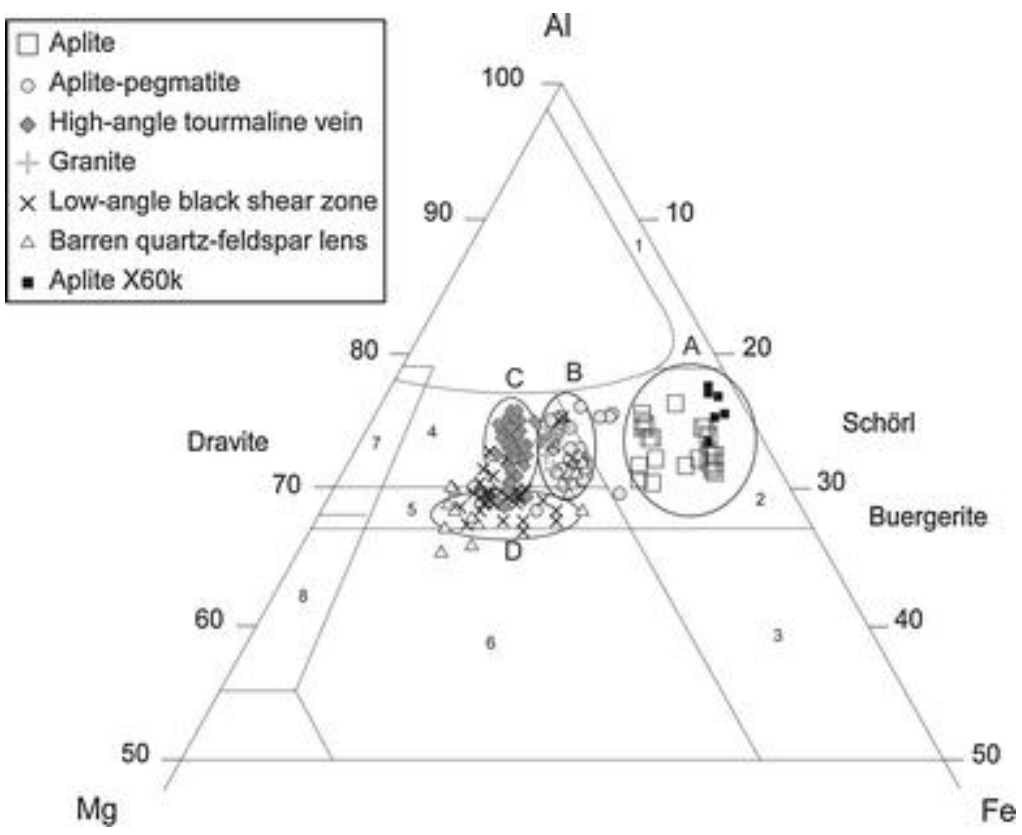

Fig. 7 Chemical composition of the different tourmalines within the $\mathrm{Al}_{50} \mathrm{Mg}_{50}-\mathrm{Al}-\mathrm{Al}_{50} \mathrm{Fe}_{50}$ diagram of Henry and Guidotti (1985). The different domains indicated by numbers are (1) Li-rich granite, pegmatite, and aplite; (2) Li-poor granite, pegmatite, and aplite; (3) granite affected by hydrothermal alteration; (4) and (5) Al-saturated metapelite and Al-unsaturated metapsammite; (6) quartztourmaline rocks and $\mathrm{Fe}^{3+}$-rich metapelite; (7) Ca-poor ultramafic rocks and $\mathrm{V}$-Cr-rich metasediment; (8) metacarbonate and metapyroxenite 


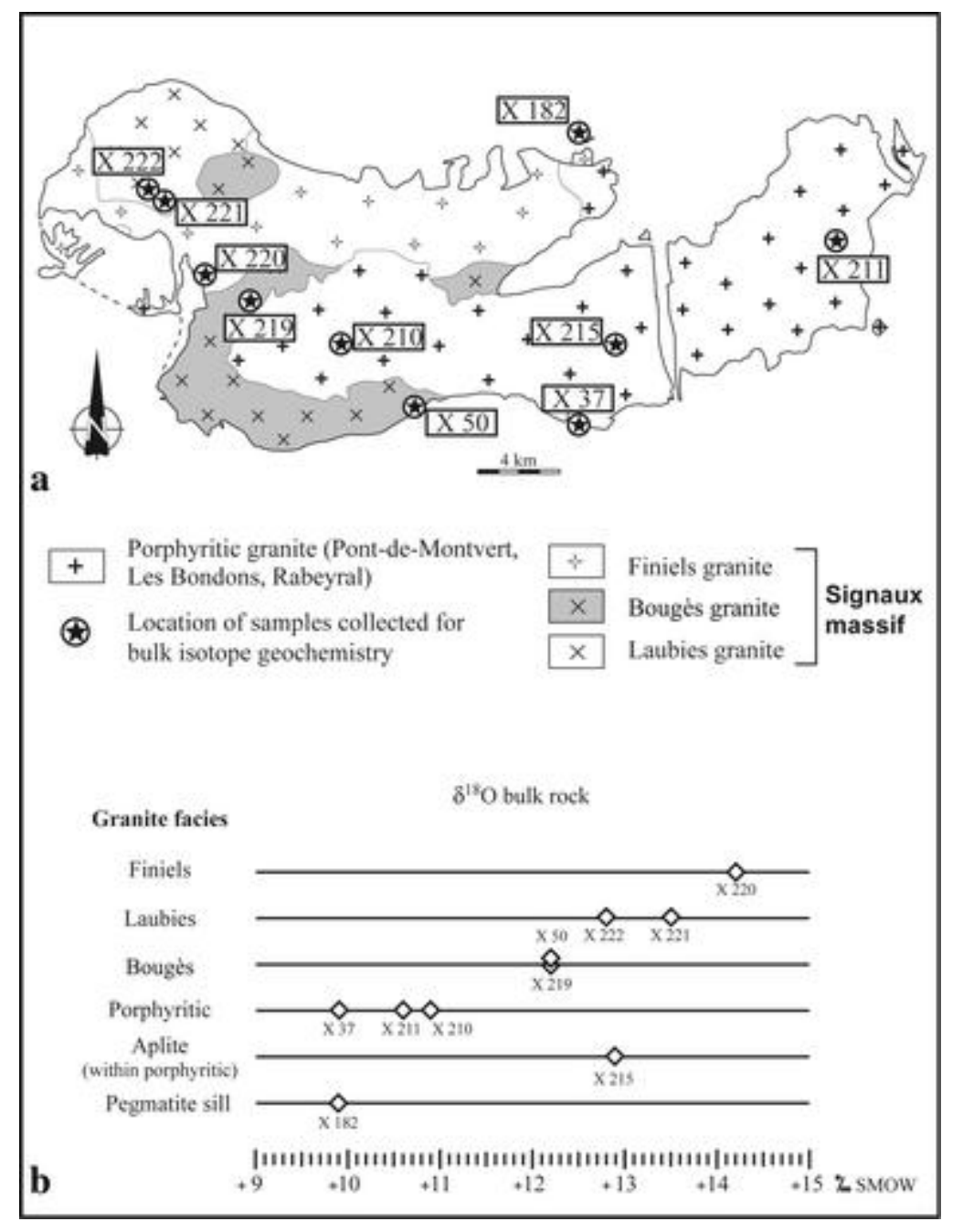

Fig. 8 a Location of samples selected for bulk-rock analysis within the Mont-Lozère-Borne plutonic complex. b $(\mathrm{O})$ isotopic data obtained on bulk-rock of the different facies of the Mont-Lozère-Borne plutons. See the text for discussion 


\section{Ar/Ar dating of magmatic features}

(all data are obtained on white mica)

a Pegmatite - Finiels cross-section Sample CE71c

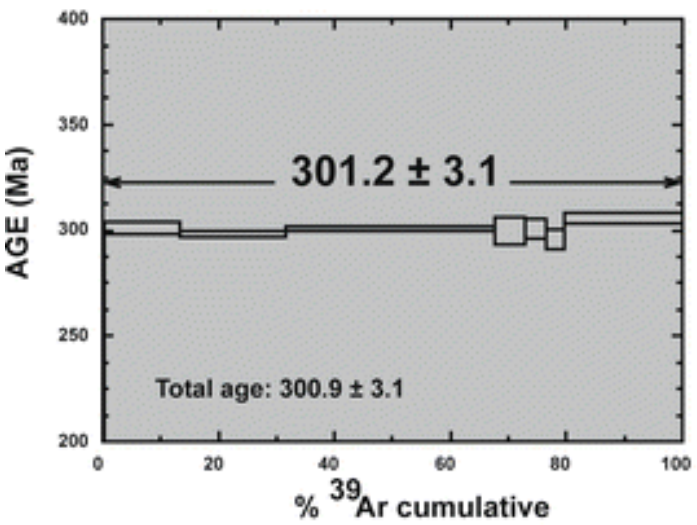

b Aplite-pegmatite - Ste-Melany Sample CE70

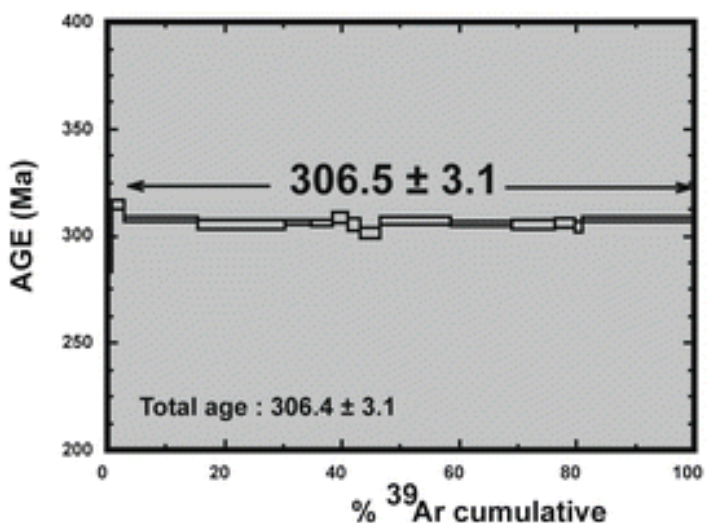

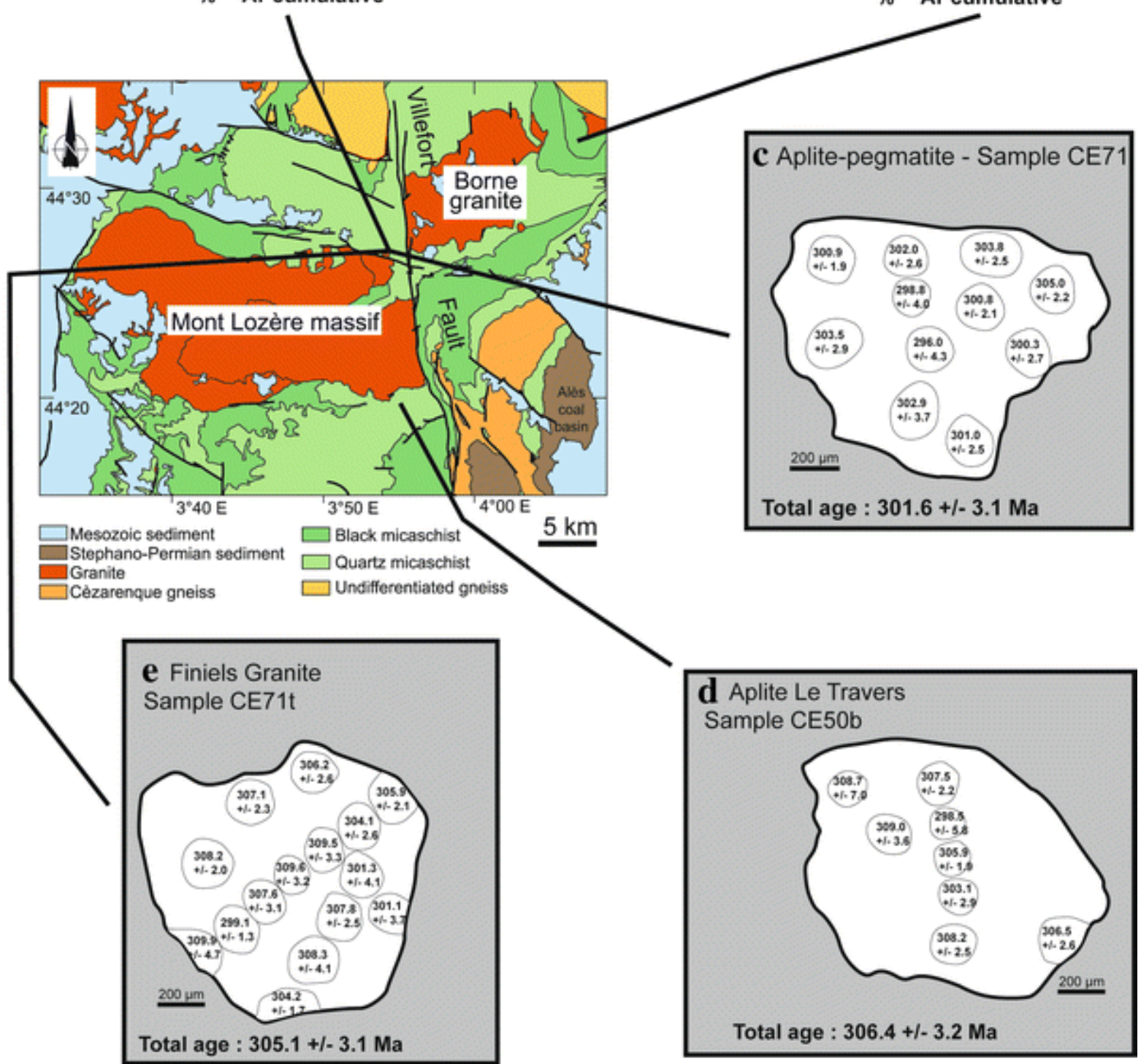

Fig. 9 Age spectra and map of laser probe fusion age for magmatic samples analyzed for ${ }^{40} \mathrm{Ar} /{ }^{39} \mathrm{Ar}$ dating. See the text for explanation 


\section{Ar/Ar dating of hydrothermal features}

(all data are muscovite grains)

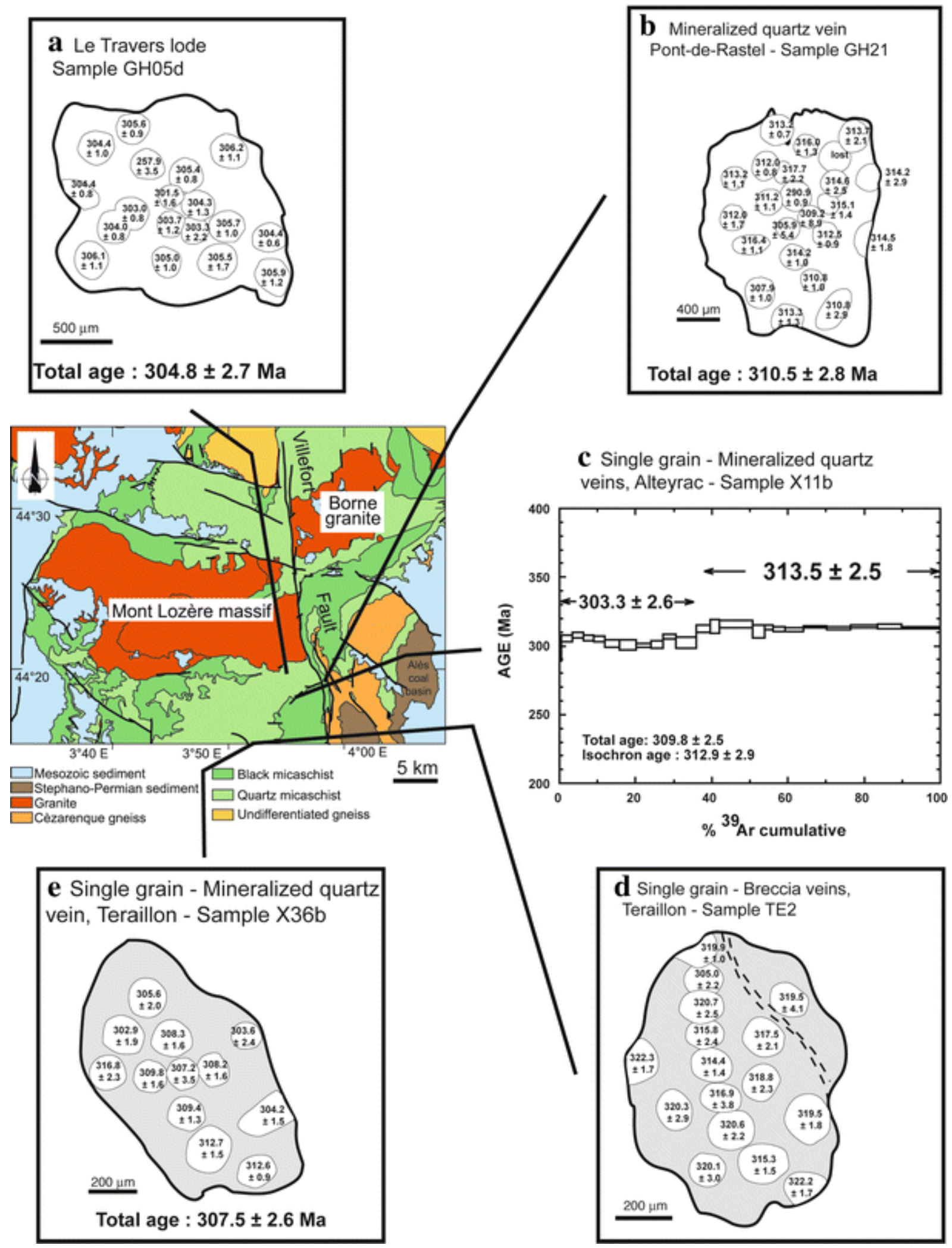

Fig. 10 Age spectra and map of laser probe fusion age for hydrothermal samples analyzed for ${ }^{40} \mathrm{Ar} /{ }^{39} \mathrm{Ar}$ dating. See the text for explanation 


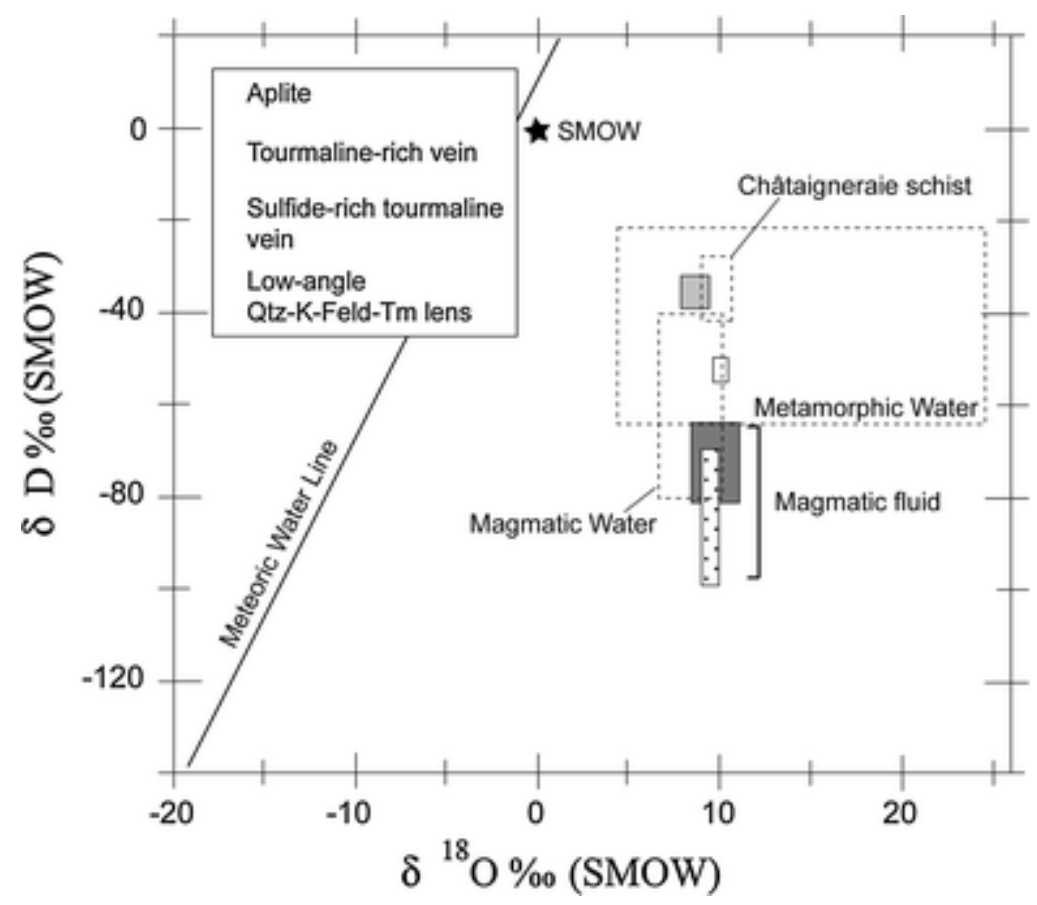

Fig. 11 Report of the analyzed tourmaline within a $\delta^{18} \mathrm{O}$ vs $\delta \mathrm{D}$ diagram in order to compare and discuss their formation with respect of the theoretical magmatic and metamorphic fields. Domain of tourmaline in micaschist found within the La Chataigneraie district is indicated for discussion (Lerouge et al. 2000). Qtz quartz, $K$-feld potassic feldspar, Tm tourmaline 